\title{
Binuclear $\mathrm{Cu}^{\mathrm{II}}$ Complexes as Catalysts for Hydrocarbon and Catechol Oxidation Reactions with Hydrogen Peroxide and Molecular Oxygen
}

\author{
Luciana R. Martins, ${ }^{a}$ Elizabeth T. Souza, ${ }^{a}$ Tatiana L. Fernandez, ${ }^{a}$ Bernardo de Souza, ${ }^{b}$ \\ Sílvio Rachinski, ${ }^{c}$ Carlos B. Pinheiro, ${ }^{d}$ Roberto B. Faria,${ }^{a}$ Annelise Casellato, ${ }^{a}$ \\ Sérgio P. Machado, ${ }^{a}$ Antonio S. Mangrich ${ }^{*, c}$ and Marciela Scarpellini ${ }^{*, a}$
}

\author{
${ }^{a}$ Departamento de Química Inorgânica, Instituto de Química, Universidade Federal do Rio de Janeiro, \\ 21945-970 Rio de Janeiro-RJ, Brazil
}

${ }^{b}$ Departamento de Química, Universidade Federal de Santa Catarina, 88040-900 Florianópolis-SC, Brazil

${ }^{c}$ Departamento de Química, Universidade Federal do Paraná, 81531-970 Curitiba-PR, Brazil

${ }^{d}$ Departamento de Física, Instituto de Ciências Exatas, Universidade Federal de Minas Gerais, 31270-901 Belo Horizonte-MG, Brazil

Dois ligantes tridentados, HL1, [(2-hidroxibenzil)(2-(imidazol-2-il)etil)]amina, e HL2, [(2-hidroxibenzil)(2-(piridil2-il)etil]amina, foram usados na síntese dos complexos binucleares $\left[\mathrm{Cu}_{2}(\mathrm{~L} 1)_{2}\right] \mathrm{Cl}_{2} \cdot 2 \mathrm{H}_{2} \mathrm{O}$, complexo $\mathbf{1}$, e $\left[\mathrm{Cu}_{2}(\mathrm{~L} 2)_{2}\right]$ $\left(\mathrm{ClO}_{4}\right)_{2} \cdot 1.5 \mathrm{H}_{2} \mathrm{O}$, complexo 2 , para serem empregados como catalisadores em processos de oxidação. Os complexos foram caracterizados por análise elementar e espectroscopias na região do infravermelho, ultravioleta-visível e ressonância paramagnética eletrônica. Foram também estudados por voltametria cíclica e titulação potenciométrica, a fim de caracterizar seus comportamentos em solução. A resolução da estrutura cristalina do complexo 1 mostrou um cátion binuclear contendo dois grupos fenóxido em ponte. Este arranjo possui uma distância $\mathrm{Cu} \cdots \mathrm{Cu}$ de 3.043(10) $\mathrm{A}$, similar à observada na catecol oxidase $(2.90 \AA$ A). Os comportamentos catalíticos destes complexos foram investigados nas oxidações de cicloexano e de catecol. Na oxidação de cicloexano observou-se baixa atividade para ambos os complexos, que pode ser atribuída ao estereoimpedimento produzido pela falta de coplanaridade entre os anéis aromáticos do arcabouço dos ligantes, sugerindo que a aproximação entre o substrato e o centro ativo binuclear é uma etapa determinante no mecanismo da reação. Com relação à atividade de catecolase, foram observadas altas eficiências, com o complexo 2 sendo mais ativo que o complexo 1. Isto indica que o ligante piridina é capaz de estabilizar melhor o intermediário proposto para esse processo, que contém o centro $\mathrm{Cu}^{\mathrm{I}} \mathrm{Cu}^{\mathrm{I}}$. Isto é corroborado pela grande participação da piridina no LUMO (lowest unoccupied molecular orbital) do complexo 2 , que pode ajudar a acomodar a carga negativa adicional quando o complexo é reduzido da forma $\mathrm{Cu}^{\mathrm{II}} \mathrm{Cu}^{\mathrm{II}}$ para $\mathrm{Cu}^{\mathrm{I}} \mathrm{Cu}^{\mathrm{I}}$.

The tridentate ligands HL1, [(2-hydroxybenzyl)(2-(imidazol-2-yl)ethyl)]amine, and HL2, [(2-hydroxybenzyl) (2-(pyridil-2-yl)ethyl]amine, were used to synthesize binuclear $\mathrm{Cu}^{\mathrm{II}}$ complexes, $\left[\mathrm{Cu}_{2}(\mathrm{~L} 1)_{2}\right] \mathrm{Cl}_{2} \cdot 2 \mathrm{H}_{2} \mathrm{O}$, complex $\mathbf{1}$, and $\left[\mathrm{Cu}_{2}(\mathrm{~L} 2)_{2}\right]\left(\mathrm{ClO}_{4}\right)_{2} \cdot 1.5 \mathrm{H}_{2} \mathrm{O}$, complex 2 , in order to obtain catalysts for oxidative processes. Both complexes were characterized by elemental analysis, IR, UV-Vis and EPR spectroscopies. In addition, they were studied by cyclic voltammetry and potentiometric titration in order to investigate their behavior in solution. The crystal structure of complex 1 revealed a binuclear cation where the metal centers are bridged by two phenoxo groups. This arrangement provides a $\mathrm{Cu} \cdots \mathrm{Cu}$ distance of 3.043(10) $\AA$, which is similar to the observed for catechol oxidase $(2.90 \AA)$. The catalytic reactivities of both complexes were investigated for hydrocarbon and catechol oxidations. Complexes $\mathbf{1}$ and $\mathbf{2}$ led to low overall hydrocarbon oxidation conversion values of $6.34 \%$ and $7.15 \%$, respectively. However, for complex 1, only cyclohexanol $(\mathrm{Cy}-\mathrm{OH})$ and cyclohexanone $(\mathrm{Cy}=\mathrm{O})$ were isolated as reaction products, with selectivities of $68.1 \%$ for $\mathrm{Cy}-\mathrm{OH}$. This low overall conversion is tentatively attributed to steric hindrance effects produced by the non-coplanar aromatic rings of the ligand scaffolds, which suggest that the access of the hydrocarbon molecule to the binuclear active center is a determinant step in the reaction mechanism. Investigation of catecholase activities has shown high efficiencies, with complex 2 being more active than complex $\mathbf{1}$. It indicates that the pyridine-containing ligand is able to stabilize the intermediate $\mathrm{Cu}^{\mathrm{I}} \mathrm{Cu}^{\mathrm{I}}$ center which is proposed to be formed in this process. This is corroborated by the strong participation of pyridine in the LUMO (lowest unoccupied molecular orbital) of complex 2, which can help to accommodate the additional negative charge when the complex is reduced from $\mathrm{Cu}^{\mathrm{II}} \mathrm{Cu}^{\mathrm{II}}$ to $\mathrm{Cu}^{\mathrm{I}} \mathrm{Cu}^{\mathrm{I}}$.

Keywords: binuclear copper complexes, molecular structure, hydrocarbon oxidation, catechol oxidase

*e-mail: mangrich@quimica.ufpr.br, marciela@iq.ufrj.br 


\section{Introduction}

Bleaching processes are among the most outstanding oxidative processes worldwide. They are largely employed in household, hospitals, commercial installations and in a variety of industries, such as textile, pulp and paper, and detergents. ${ }^{1}$ Actually, chlorine-based bleaching systems including chlorine gas, chlorites $\left(\mathrm{Ca}\left(\mathrm{ClO}_{2}\right)_{2}\right.$ and $\left.\mathrm{NaClO}_{2}\right)$, hypochlorites $\left(\mathrm{NaOCl}, \mathrm{Ca}(\mathrm{OCl})_{2}\right)$ and chlorine dioxide $\left(\mathrm{ClO}_{2}\right)$ are largely employed. ${ }^{2}$ However, environmental concerns have led to restrict their use mainly because of the resulting chlorine-based residuals. ${ }^{3}$ This restriction focuses basically on their chlorinated organic subproducts that are potentially hazardous, present low biodegradability, are recalcitrant, and then considered not environmentally friendly. In order to overcome the disadvantages of chlorine-containing products, totally chlorine free (TCF) systems emerged as an alternative, including molecular oxygen, ozone, hydrogen peroxide, perborates, percarbonates, enzymes and others. ${ }^{4}$ Under the green chemistry concept, some strategies are being spread out, as the use of enzymes able to activate oxygen, or hydrogen peroxide, to perform oxidation reactions. ${ }^{5,6}$ This class of enzymes is called oxidoreductases and comprises several copper-containing metalloenzymes such as laccases, ${ }^{7}$ tyrosinase, ${ }^{8,9}$ catechol oxidase ${ }^{10}$ and $\mathrm{Cu}$-containing quercetinase. ${ }^{11,12}$ Laccase is probably the most employed in bleaching studies. It is a multi-copper containing oxidoreductase (EC 1.10.3.2) with four copper centers (one type 1, one type 2 and two type $3 \mathrm{Cu}$ atoms), which catalyzes the oxidation of a variety of phenols to quinones through the activation of molecular oxygen. ${ }^{13}$ Laccase has been studied in several organic transformations such as the preparation of phenolderivatives, aldehydes, ketones, lactones, oxidations of azo-dyes, hormones, polymerization reactions, and others. ${ }^{13}$
In addition to copper-containing laccase, tyrosinase and catechol oxidase have also received special attention related to their use as green catalysts because of their catecholase activity, i.e., their ability to convert 1,2-dihydroxyphenols (o-diphenol or catechol) to the respective $o$-quinones. However, besides this feature, tyrosinase is also able to promote the $o$-hydroxylation of phenols (cresolase activity) and may contribute to bioremediation of phenol-containing industrial residues. ${ }^{7}$ Unlike laccase, both tyrosinase and catechol oxidase are binuclear (type 3) copper enzymes. Despite tyrosinase crystal structure has not been solved, several spectroscopic studies indicate a close similarity with catechol oxidase. In the met form, catechol oxidase presents two $\mathrm{Cu}^{\mathrm{II}}$ ions coordinated to three histidine residues each, bridged by a hydroxo group $2.87 \AA$ apart. ${ }^{14}$

Considering the high academic and industrial interest on these enzyme systems, and that their use is sometimes limited mainly because of the optimal $\mathrm{pH}$ and temperature ranges,${ }^{15}$ model complexes are considered as an alternative. Because of this, several compounds have been synthesized, characterized and tested as catalysts for oxidative processes involving molecular oxygen and hydrogen peroxide. ${ }^{16}$ It is a matter of great concern to understand how small changes on the ligand scaffold can interfere in the reactivity of copper-containing coordination complexes, in order to improve their efficiency. ${ }^{17}$

In view of our previous interest in copper model complexes and in polipodal ligands, ${ }^{18-22}$ we present here two new binuclear $\mathrm{Cu}^{\mathrm{II}}$ complexes (1 and 2, Figure 1) employing the tridentate $\mathrm{N}, \mathrm{O}$-donor ligands $\mathrm{HL} 1$, [(2-hydroxybenzyl)(2-(imidazol-2-yl)ethyl)]amine, and HL2, [(2-hydroxybenzyl)(2-(pyridil-2-yl)ethyl]amine. These complexes were designed intending to develop new catalysts for oxidative processes, and their reactivity towards cyclohexane and catechol oxidation reactions were investigated using hydrogen peroxide or molecular oxygen as oxidants.
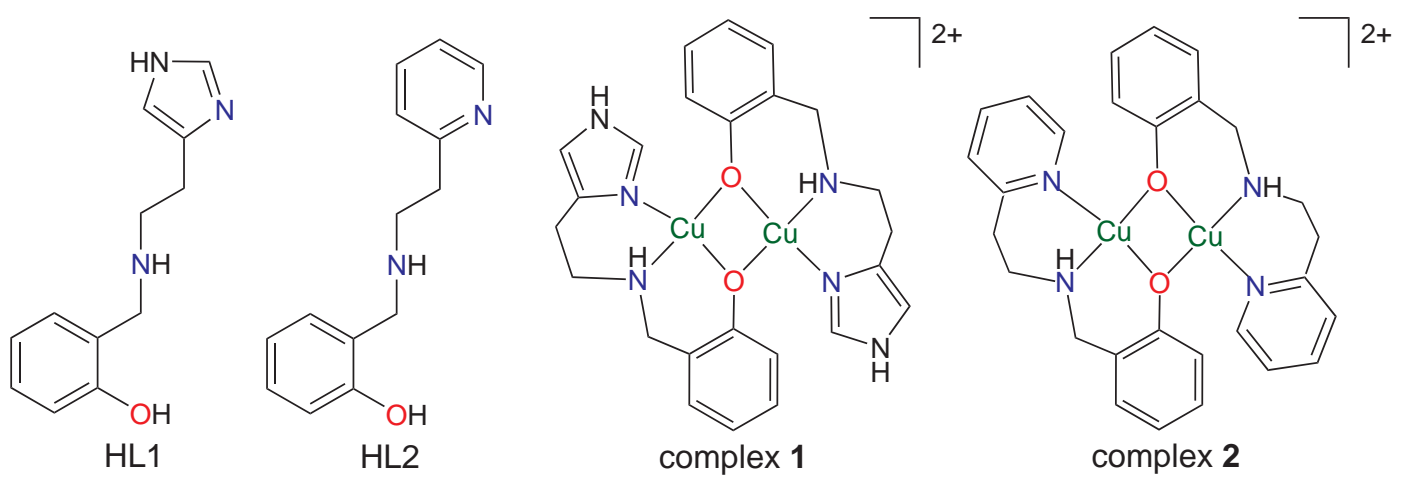

Figure 1. Schematic views of HL1, HL2 and complexes $\mathbf{1}$ and 2. 


\section{Experimental}

\section{Materials and measurements}

HL1 and HL2 were synthesized and purified as previously described. ${ }^{23,24}$ All chemicals for syntheses and analyses were of analytical grade and used without further purification. Infrared spectra (CsI pellet or film) were recorded using a NICOLET, MAGNA-IR 760 (4000 to $200 \mathrm{~cm}^{-1}$ ) spectrophotometer. Elemental analyses were performed using a Perkin-Elmer 2400 analyzer coupled to an AD-4 Perkin-Elmer microbalance. Electronic absorption spectra were recorded using a Perkin-Elmer Lambda-19 spectrophotometer. Cyclic voltammetry studies were performed with a Princeton Applied Research (PAR) 273 potentiostat, at room temperature $\left(25 \pm 1^{\circ} \mathrm{C}\right)$, in acetonitrile solutions kept under argon atmosphere. The standard three-electrode cell was composed by the following electrodes: a glassy carbon working, a platinum auxiliary and a $\mathrm{Ag} / \mathrm{AgCl}$ pseudo-reference. Hexafluorophosphate of tetrabutylammonium ( $\mathrm{tba}\left(\mathrm{PF}_{6}\right), 0.1 \mathrm{~mol} \mathrm{~L}^{-1}$ ) was used as supporting electrolyte and the ferrocenium-ferrocene couple ${ }^{25}$ was employed to monitor the reference electrode potential. Molar conductivities were measured on a Digimed CD-21 conductivity meter in methanol solutions.

\section{Syntheses}

$\left[\mathrm{Cu}_{2}(\mathrm{Ll})_{2}\right] \mathrm{Cl}_{2} \cdot 2 \mathrm{H}_{2} \mathrm{O}, \mathrm{I}$

Complex 1 was obtained by the slow addition of $\mathrm{CuCl}_{2} \cdot 2 \mathrm{H}_{2} \mathrm{O}(0.17 \mathrm{~g}, 1 \mathrm{mmol}$ in $20 \mathrm{~mL}$ of methanol $)$ to a methanolic solution of HL1 $(0.217 \mathrm{~g}, 1 \mathrm{mmol}$ in $20 \mathrm{~mL})$. The reaction mixture was heated under stirring for $c a$. $15 \mathrm{~min}$, filtered and left to crystallize on bench at room temperature (near $25^{\circ} \mathrm{C}$ ). After a few days, dark green single crystals suitable for X-ray crystallographic analysis were collected from the mother liquor. Decomposition point: $195{ }^{\circ} \mathrm{C}$. FTIR $\left(\mathrm{CsI}, \mathrm{cm}^{-1}\right): \mathrm{v}\left(\mathrm{NH}_{\mathrm{sec}}\right) 3134 ; \mathrm{v}\left(\mathrm{CH}_{\mathrm{ar}} / \mathrm{CH}_{\mathrm{alif}}\right)$ 3037-2909; $v(C=N / C=C)$ 1596-1454; $v(C-O) 1275$ and $\delta\left(\mathrm{CH}_{\mathrm{ar}}\right)$ 771. Elemental analysis calculated (found) for $\mathrm{C}_{24} \mathrm{H}_{28} \mathrm{Cl}_{2} \mathrm{Cu}_{2} \mathrm{~N}_{6} \mathrm{O}_{2} \cdot 2 \mathrm{H}_{2} \mathrm{O}: \mathrm{C} 43.25$ (43.11); $\mathrm{H} 4.84$ (4.61); $\mathrm{N} 12.61(12.87) \% . \Lambda_{\mathrm{M}}=151 \Omega^{-1} \mathrm{~mol}^{-1} \mathrm{~cm}^{2}$ (electrolyte $2: 1$ in methanol). ${ }^{26}$

\section{$\left[\mathrm{Cu}_{2}\left(\mathrm{~L} 2_{2}\right)_{2}\right]\left(\mathrm{ClO}_{4}\right)_{2} \cdot 1.5 \mathrm{H}_{2} \mathrm{O}, 2$}

Complex 2 was synthesized by the same procedure described for complex $\mathbf{1}$, but with the addition of excess of sodium perchlorate at the end of reaction. Dark green single crystals were also obtained from the mother liquor, but none of them presented a satisfactory diffraction pattern. Recrystallizations in other media failed. Decomposition point: $229^{\circ} \mathrm{C} . \mathrm{FTIR}\left(\mathrm{CsI}, \mathrm{cm}^{-1}\right): \mathrm{v}\left(\mathrm{NH}_{\mathrm{sec}}\right) 3240 ; \mathrm{v}\left(\mathrm{CH}_{\mathrm{ar}} / \mathrm{CH}_{\mathrm{alif}}\right)$ 3072-2941; $v(\mathrm{C}=\mathrm{N} / \mathrm{C}=\mathrm{C})$ 1610-1423; $\mathrm{v}(\mathrm{C}-\mathrm{O}) 1259 ; \mathrm{v}(\mathrm{Cl}-\mathrm{O})$ 1130-1028 and $\delta\left(\mathrm{CH}_{\text {ar }}\right) 775$. Elemental analysis calculated (found) for $\mathrm{C}_{28} \mathrm{H}_{30} \mathrm{Cl}_{2} \mathrm{Cu}_{2} \mathrm{~N}_{4} \mathrm{O}_{10} \cdot 1.5 \mathrm{H}_{2} \mathrm{O}: \mathrm{C} 41.64$ (41.61); $\mathrm{H} 4.12$ (3.79); N 6.94 (6.54)\%. $\Lambda_{\mathrm{M}}=162 \Omega^{-1} \mathrm{~mol}^{-1} \mathrm{~cm}^{2}$ (electrolyte $2: 1$ in methanol). ${ }^{26}$

Warning: perchlorate salts are potentially explosive and must be handled very carefully and only in small quantities.

\section{Potentiometric titration}

Potentiometric studies were carried out in $\mathrm{CH}_{3} \mathrm{CN} / \mathrm{H}_{2} \mathrm{O}$ $(1: 1 \mathrm{v} / \mathrm{v})$ solution using a Micronal B375 pHmeter fitted with blue-glass and calomel reference electrodes calibrated to read $-\log \left[\mathrm{H}^{+}\right]$directly, designated as $\mathrm{pH}$. Bidistilled water in the presence of $\mathrm{KMnO}_{4}$ was used to prepare the $\mathrm{CH}_{3} \mathrm{CN} / \mathrm{H}_{2} \mathrm{O}(1: 1 \mathrm{v} / \mathrm{v})$ solutions. The electrode was calibrated using the data obtained from a potentiometric titration of a known volume of a standard $0.0100 \mathrm{~mol} \mathrm{~L}^{-1}$ $\mathrm{HCl}$ solution $\left(0.1 \mathrm{~mol} \mathrm{~L}^{-1}\right.$ in $\left.\mathrm{KCl}\right)$ with a standard $\mathrm{CO}_{2}$ free $0.100 \mathrm{~mol} \mathrm{~L}^{-1} \mathrm{KOH}$ solution. The measurements were carried out in a thermostatized cell containing a solution of the complex $(0.05 \mathrm{~mol} / 50 \mathrm{~mL})$ with ionic strength adjusted to $0.100 \mathrm{~mol} \mathrm{~L}^{-1}$ by addition of $\mathrm{KCl}$, at $25.00 \pm 0.05{ }^{\circ} \mathrm{C}$. The experiments were performed under argon flow to eliminate the presence of atmospheric $\mathrm{CO}_{2}$. The samples were titrated by addition of fixed volumes of a standard $\mathrm{CO}_{2}$-free $\mathrm{KOH}$ solution $\left(0.100 \mathrm{~mol} \mathrm{~L}^{-1}\right)$. Computations were carried out with the BEST program, and species diagrams were obtained with SPE and SPEPLOT programs. ${ }^{27}$

\section{Crystal structure}

X-ray diffraction data collection for compound $\mathbf{1}$ was performed on a Bruker-Kappa-CCD diffractometer (LDRX) using graphite-monochromatized Mo-K $\mathrm{K}_{\alpha}$ radiation $(\lambda=0.71069 \AA)$ at room temperature. Final unit cell parameters were based on the fitting of all reflections positions. ${ }^{28}$ Data integration and scaling of the reflections were performed with the EVALCCD suite. ${ }^{29}$ Empirical multiscan absorption corrections using equivalent reflections were performed with the program SADABS. ${ }^{30}$ The structure was solved by direct methods using the SHELXS ${ }^{31}$ program. The positions of all atoms could be unambiguously assigned on consecutive difference Fourier maps. Refinements were performed using SHELXL ${ }^{31}$ based on $\mathrm{F}^{2}$ through full-matrix least square routine. All but hydrogen atoms were refined with anisotropic atomic displacement parameters. Hydrogen atoms were added to the structure and further refined according to the riding model. ${ }^{32}$ No disordered groups have been found 
in the structure refinements. All attempts to localize the hydrogen atoms around the water molecules failed. Thus, the hydrogen bonds of the $\mathrm{N}-\mathrm{H}$ group of the imidazole towards the water molecules could not be properly assigned. Crystal structure and refinement data for complex $\mathbf{1}$ are summarized in Table 1. Selected bond distances and angles are indicated in Table 2. Atomic coordinates and complete crystal structure results are given as supplementary information (see SI).

\section{Reactivity}

\section{Cyclohexane oxidation}

The catalytic activities of complexes $\mathbf{1}$ and $\mathbf{2}$ towards cyclohexane oxidation were determined following previously published methods. ${ }^{33}$ The reaction was performed in acetonitrile at room temperature and inert atmosphere, using $\mathrm{H}_{2} \mathrm{O}_{2}$ as oxidant. The catalyst:substrate:oxidant reaction ratio was 1:1000:1000, with a catalyst concentration of $7 \times 10^{-4} \mathrm{~mol} \mathrm{~L}^{-1}$. In a typical experiment, the catalytic reaction was triggered with the addition of cyclohexane to a degassed acetonitrile solution containing the catalyst and the oxidant. The reaction was quenched after $24 \mathrm{~h}$ with the addition of an aqueous solution of $\mathrm{Na}_{2} \mathrm{SO}_{4}\left(0.4 \mathrm{~mol} \mathrm{~L}^{-1}\right)$. The products were extracted with diethyl ether; the organic fractions were dried over anhydrous $\mathrm{Na}_{2} \mathrm{SO}_{4}$ and analyzed by gas chromatography. The results are expressed as relative yields. $^{33}$

\section{Oxidation of 3,5-di-tert-butyl-catechol}

The cathecolase activities of complexes $\mathbf{1}$ and $\mathbf{2}$ were measured by the oxidation of 3,5-di-tert-butylcatechol (3,5$\mathrm{dtbc}$ ) to the respective quinone at $25^{\circ} \mathrm{C}$. The experiments were performed with an Agilent 8453 spectrophotometer, and the reactions were followed at $400 \mathrm{~nm}$, which is the characteristic absorption band of the oxidation product (3,5-di-tert-butylquinone, 3,5-dtbq). The $\mathrm{pH}$ effect on the reaction rate was determined over the $\mathrm{pH}$ range 5.5-10.0. A typical experiment was performed using the following conditions: $100 \mu \mathrm{L}$ of freshly prepared aqueous buffer solution, $[\text { buffer }]_{\text {final }}=3 \times 10^{-3} \mathrm{~mol} \mathrm{~L}^{-1}$ (buffers: MES (2-( $N$-morpholino)ethanesulfonic acid), $\mathrm{pH}$ 5.5, 6.0 and 6.5; HEPES (4-(2-hydroxyethyl)piperazine-1-ethanesulfonic acid), $\mathrm{pH} 7.0$ and 7.5; and CHES (2-(cyclohexylamino) ethanesulfonic acid), 8.0, 8.5, 9.0, 9.5 and 10.0), $100 \mu \mathrm{L}$ of a methanolic solution of the complex $\left([\mathrm{complex}]_{\text {final }}=\right.$ $2.4 \times 10^{-5} \mathrm{~mol} \mathrm{~L}^{-1}$ ) and $3.0 \mathrm{~mL}$ of $\mathrm{O}_{2}$-saturated methanol. A 1 -cm-path-length quartz cell was used as a reactor. The kinetic experiments under conditions of excess of substrate
Table 1. Crystal structure data collection and refinement for compound $\mathbf{1}$

\begin{tabular}{|c|c|}
\hline & Complex 1 \\
\hline Empirical formula & $\mathrm{C}_{24} \mathrm{H}_{28} \mathrm{Cl}_{2} \mathrm{Cu}_{2} \mathrm{~N}_{6} \mathrm{O}_{4}$ \\
\hline Formula weight & 666.50 \\
\hline Temperature (K) & $298(2)$ \\
\hline Wavelength $(\lambda, \AA)$ & 0.71073 \\
\hline Crystal system & Monoclinic \\
\hline Space group & $C \mathrm{c}$ \\
\hline Unit cell dimensions: $a(\AA)$ & $16.524(3)$ \\
\hline$b(\AA)$ & $12.745(3)$ \\
\hline$c(\AA)$ & $15.735(3)$ \\
\hline$\alpha(\operatorname{deg})$ & 90 \\
\hline$\beta(\operatorname{deg})$ & $117.79(3)$ \\
\hline$\gamma(\operatorname{deg})$ & 90 \\
\hline Volume $\left(\AA^{3}\right)$ & 2931.4(13) \\
\hline $\mathrm{Z}$ & 4 \\
\hline Density $\left(\rho_{\text {calc }}, \mathrm{g} \mathrm{cm}^{-3}\right)$ & 1.501 \\
\hline Absorption coefficient $\left(\mu, \mathrm{mm}^{-1}\right)$ & 1.673 \\
\hline $\mathrm{F}(000)$ & 1352 \\
\hline Crystal size $\left(\mathrm{mm}^{3}\right)$ & $0.42 \times 0.19 \times 0.11$ \\
\hline Theta range for data collection (deg) & 5.09 to 26.37 \\
\hline Index ranges & $\begin{array}{r}-20 \leq \mathrm{h} \leq 20 \\
-15 \leq \mathrm{k} \leq 15 \\
-19 \leq 1 \leq 19\end{array}$ \\
\hline Reflections collected & 13418 \\
\hline Independent reflections & $5123[\mathrm{R}($ int $)=0.0381]$ \\
\hline Completeness to $\theta=26.37^{\circ}(\%)$ & 98.3 \\
\hline Refinement method & Full-matrix least-squares on $\mathrm{F}^{2}$ \\
\hline Data / restraints / parameters & $5123 / 2 / 345$ \\
\hline Goodness-of-fit on $\mathrm{F}^{2}$ & 1.160 \\
\hline Final $\mathrm{R}$ indices [I>2sigma(I)] & $\mathrm{R}_{1}=0.0435, \mathrm{wR}_{2}=0.0841$ \\
\hline $\mathrm{R}$ indices (all data) & $\mathrm{R}_{1}=0.0792, \mathrm{wR}_{2}=0.1023$ \\
\hline Largest diff. peak and hole $\left(\mathrm{e} \AA^{-3}\right)$ & 0.613 and -0.439 \\
\hline
\end{tabular}

were performed using $100 \mu \mathrm{L}$ of freshly prepared aqueous CHES buffer, $100 \mu \mathrm{L}$ of a methanolic solution of the complex ([complex $\left.]_{\text {final }}=2.4 \times 10^{-5} \mathrm{~mol} \mathrm{~L}^{-1}\right)$ and oxygen-

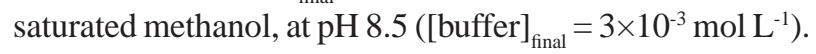
The reaction was initiated by the addition of volumes varying from $60 \mu \mathrm{L}$ to $240 \mu \mathrm{L}$ of a 3,5-dtbc solution ([3,5$\mathrm{dtbc}_{\text {final }} 3 \times 10^{-3}-12 \times 10^{-3} \mathrm{~mol} \mathrm{~L}^{-1}$ ) and monitored for $20 \mathrm{~min}$. Correction for the spontaneous oxidation of the 3,5-dtbc was carried out by subtracting the initial rate for the blank experiment (without adding the catalyst). The initial rate at each substrate concentration was obtained by fitting a second degree polynomial to the absorbance $v s$. time plot,,$^{34}$ using $\varepsilon(400 \mathrm{~nm})=1900 \mathrm{~mol} \mathrm{~L}^{-1} \mathrm{~cm}^{-1}$ for 3,5-di-tertbutylquinone..$^{35} \mathrm{~A}$ Michaelis-Menten approach was applied using a non-linear fit to obtain $V_{\max }$ and $K_{\mathrm{M}}$ parameters. ${ }^{36}$ 
Table 2. Experimental (X-ray) and calculated (DFT) main bond distances $(\AA)$ and angles $\left(^{\circ}\right)$ for complexes $\mathbf{1}$ and $\mathbf{2}$

\begin{tabular}{|c|c|c|c|}
\hline & \multicolumn{2}{|c|}{ Complex 1} & \multirow{2}{*}{$\begin{array}{c}\text { Complex } 2 \\
\text { Calc }\end{array}$} \\
\hline & Exp & Calc & \\
\hline $\mathrm{Cu}(01)-\mathrm{N}(010)$ & $1.959(5)$ & 1.976 & 2.018 \\
\hline $\mathrm{Cu}(01)-\mathrm{O}(006)$ & $1.980(4)$ & 1.966 & 1.976 \\
\hline $\mathrm{Cu}(01)-\mathrm{O}(005)$ & $2.000(4)$ & 2.010 & 2.006 \\
\hline $\mathrm{Cu}(01)-\mathrm{N}(009)$ & $2.030(5)$ & 2.082 & 2.056 \\
\hline $\mathrm{Cu}(01)-\mathrm{Cl}(03)$ & $2.745(5)$ & & \\
\hline $\mathrm{Cu}(01)-\mathrm{O}(01)$ & $4.430(5)$ & & \\
\hline $\mathrm{Cu}(01)-\mathrm{O}(02)$ & 3.928 & & \\
\hline $\mathrm{Cu}(01)-\mathrm{Cu}(02)$ & $3.043(10)$ & 3.049 & 3.064 \\
\hline $\mathrm{Cu}(02)-\mathrm{N}(012)$ & $1.943(5)$ & 1.976 & 2.018 \\
\hline $\mathrm{Cu}(02)-\mathrm{O}(005)$ & $1.950(4)$ & 1.967 & 1.975 \\
\hline $\mathrm{Cu}(02)-\mathrm{O}(006)$ & $1.983(4)$ & 2.082 & 2.006 \\
\hline $\mathrm{Cu}(02)-\mathrm{N}(007)$ & $2.019(5)$ & 1.960 & 2.056 \\
\hline $\mathrm{Cu}(02)-\mathrm{Cl}(04)$ & $3.174(3)$ & & \\
\hline $\mathrm{Cu}(02)-\mathrm{O}(02)$ & $2.899(4)$ & & \\
\hline $\mathrm{Cu}(02)-\mathrm{O}(01)$ & 4.302 & & \\
\hline $\mathrm{N}(010)-\mathrm{Cu}(01)-\mathrm{O}(06)$ & $146.5(2)$ & 165.32 & 159.41 \\
\hline $\mathrm{N}(010)-\mathrm{Cu}(01)-\mathrm{O}(005)$ & $93.8(2)$ & 96.15 & 96.57 \\
\hline $\mathrm{O}(006)-\mathrm{Cu}(01)-\mathrm{O}(005)$ & $76.82(17)$ & 78.80 & 78.74 \\
\hline $\mathrm{N}(010)-\mathrm{Cu}(01)-\mathrm{N}(009)$ & $95.7(2)$ & 94.62 & 96.78 \\
\hline $\mathrm{O}(006)-\mathrm{Cu}(01)-\mathrm{N}(009)$ & $92.47(19)$ & 92.22 & 91.84 \\
\hline $\mathrm{O}(005)-\mathrm{Cu}(01)-\mathrm{N}(009)$ & $169.25(19)$ & 167.45 & 163.63 \\
\hline $\mathrm{N}(012)-\mathrm{Cu}(02)-\mathrm{O}(005)$ & $157.8(2)$ & 165.24 & 159.45 \\
\hline $\mathrm{N}(012)-\mathrm{Cu}(02)-\mathrm{O}(006)$ & 92.61(19) & 92.22 & 96.77 \\
\hline $\mathrm{O}(005)-\mathrm{Cu}(02)-\mathrm{O}(006)$ & 77.91(17) & 78.80 & 78.73 \\
\hline $\mathrm{N}(012)-\mathrm{Cu}(02)-\mathrm{N}(007)$ & $96.9(2)$ & 94.60 & 96.77 \\
\hline $\mathrm{O}(005)-\mathrm{Cu}(02)-\mathrm{N}(007)$ & $94.18(19)$ & 92.21 & 91.82 \\
\hline $\mathrm{O}(006)-\mathrm{Cu}(02)-\mathrm{N}(007)$ & $170.1(2)$ & 167.32 & 163.69 \\
\hline $\mathrm{Cu}(02)-\mathrm{O}(005)-\mathrm{Cu}(01)$ & $100.79(18)$ & 100.13 & 100.56 \\
\hline $\mathrm{Cu}(01)-\mathrm{O}(006)-\mathrm{Cu}(02)$ & 100.34(19) & 100.44 & 100.62 \\
\hline
\end{tabular}

\section{Theoretical calculations}

Geometry optimizations were performed as described before, using Gaussian 03 package with the B3LYP hybrid density functional theory combined with the $6-31 \mathrm{G}^{*}$ basis sets and LANL2DZ for the $\mathrm{Cu}$ atom. ${ }^{37}$

\section{Results and Discussion}

\section{Synthesis and initial characterization}

L1 and L2 were chosen in order to provide insights about the influence of the substitution of pyridine by imidazole rings on the electronic structure and reactivity of the complexes. Both ligands are able to stabilize $\mathrm{Cu}^{\text {II }}$ complexes. Infrared spectra of complexes $\mathbf{1}$ and $\mathbf{2}$ have shown characteristic bands of the ligands scaffold, and are shifted when compared to free HL1 and HL2, which is clear evidence of complexation. In order to help band attribution, theoretical studies were carried out using DFT (Figure S2). Considering the similarities of ligands and complexes spectra, the attribution data are summarized on Table S1, and only the main differences are discussed. In both spectra of complexes $\mathbf{1}$ and $\mathbf{2}$, the out-of-the-plane $\mathrm{OH}$ angular deformation band of the phenol group is absent, indicating the presence of phenolate groups coordinated to the metal centers. For complex $\mathbf{2}$, the presence of free perchlorate anions is evidenced by a broad band from 1130 to $1028 \mathrm{~cm}^{-1}$ assigned to the $\mathrm{Cl}-\mathrm{O}$ stretchings of this anion as a counter ion.$^{38}$ For both complexes, elemental analyses indicate the 1:1 ligand:metal ratio, and the presence of chloride or perchlorate anions. The binuclear arrangement for both complexes is firstly suggested by conductivity data obtained in freshly prepared methanol solutions (complex 1: $\Lambda_{\mathrm{M}}=151 \Omega^{-1} \mathrm{~mol}^{-1} \mathrm{~cm}^{2}$, and complex 2: $\Lambda_{\mathrm{M}}=162 \Omega^{-1} \mathrm{~mol}^{-1} \mathrm{~cm}^{2}$ ), which are in the typical range of 2:1 electrolytes. ${ }^{26}$

\section{$X$-ray crystal structure}

Crystallographic data and bond parameters for complex 1 are presented in Tables 1 and 2, respectively. An ORTEP ${ }^{39}$ drawing of the cation complex is shown in Figure 2. The binuclear structure in the solid state is confirmed, where each $\mathrm{Cu}^{\mathrm{II}}$ atom is coordinated to a deprotonated $\mathrm{L} 1$, and bridged by the two phenoxo groups provided by the ligand. In close proximity, there are two chloride anions and two water molecules (Figure 2). In addition to the two

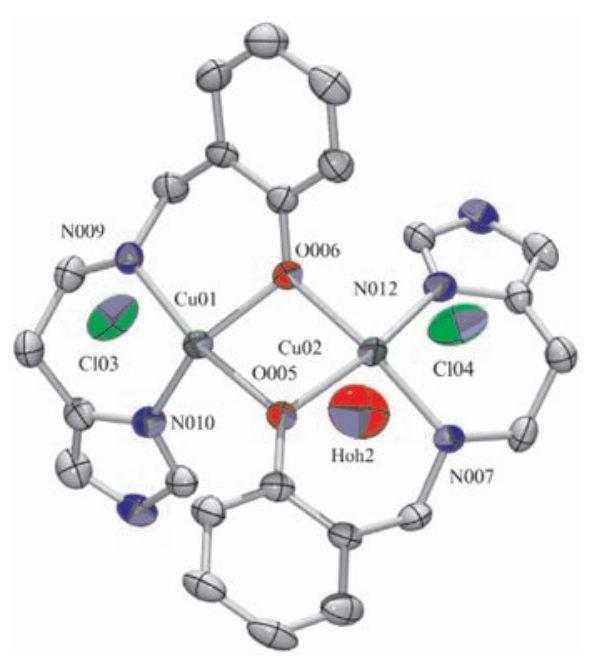

Figure 2. ORTEP ${ }^{39}$ representation of complex 1, showing the coordination sphere atoms labeling and $50 \%$ probability ellipsoids. 
oxygen atoms from the phenoxo bridges, each $\mathrm{Cu}^{\mathrm{II}}$ atom is coordinated to one imidazole and the amine nitrogen atoms. Thus, the $\mathrm{Cu}^{\mathrm{II}}$ atoms can be considered as tetracoordinated, since their distances to the chloride anions and the water molecules are longer than 2.745(5) $\AA$ (Table 2). In fact, these $\mathrm{Cu}-\mathrm{Cl}$ bond distances are longer than those reported for coordinated chloride anions..$^{19,40,41}$ The geometries adopted by the $\mathrm{Cu}^{\mathrm{II}}$ centers are both distorted square-planar, with angles varying from 76.8(2) $\AA$ to $95.7(2) \AA$, for $\mathrm{Cu}(01)$, and from 77.9(2) $\AA$ to 96.9(2) $\AA$, for $\mathrm{Cu}(02)$.

In both $\mathrm{Cu}^{\text {II }}$ centers, the shorter bond distances are $\mathrm{Cu}-\mathrm{N}_{\text {imidazole }}[\mathrm{Cu}(01)-\mathrm{N}(10)=1.959(5)$ and $\mathrm{Cu}(02)-\mathrm{N}(12)=$ 1.943(5) $\mathrm{A}]$, which are in the range observed for other $\mathrm{Cu}^{\mathrm{II}}$ complexes with imidazole-containing ligands. ${ }^{18-21,65}$ The longer ones are $\mathrm{Cu}-\mathrm{N}_{\text {amine }}[\mathrm{Cu}(01)-\mathrm{N}(09)=2.030(5)$ and $\mathrm{Cu}(02)-\mathrm{N}(07)=2.019(5) \AA]$, which also agree with this type of bond distances in $\mathrm{Cu}^{\mathrm{II}}$ complexes. ${ }^{18-21,42,43} \mathrm{Also}$ in the expected range are the distances $\mathrm{Cu}-\mathrm{O}_{\text {phenoxo }}[\mathrm{Cu}(01)-\mathrm{O}(006)=1.980(4)$, $\mathrm{Cu}(01)-\mathrm{O}(005)=2.000(4), \mathrm{Cu}(02)-\mathrm{O}(005)=1.950(4)$ and $\mathrm{Cu}(02)-\mathrm{O}(006)=1.983(4) \AA] .{ }^{24,44-46}$ Finally, the $\mathrm{Cu} \cdots \mathrm{Cu}$ distance is 3.043(10) $\AA$ and is in the range observed for other binuclear $\mathrm{Cu}^{\mathrm{II}}$ complexes bridged by two phenoxo groups. ${ }^{43,44}$ These distances are similar to that observed for the oxidized form of catechol oxidase $(2.90 \AA) .{ }^{10,17}$

\section{Spectroscopic analyses}

The electronic spectra of complexes $\mathbf{1}$ and $\mathbf{2}$ were recorded in the solid state and acetonitrile solutions (Figure 3). In both cases, the two complexes present the same electronic features, indicating that their structures are maintained in solution. In acetonitrile, the spectra of both complexes are quite similar and show bands at $635 \mathrm{~nm}$ $\left(\varepsilon=212 \mathrm{~L} \mathrm{~mol}^{-1} \mathrm{~cm}^{-1}\right)$ and $398 \mathrm{~nm}\left(\varepsilon=3,340 \mathrm{~L} \mathrm{~mol}^{-1} \mathrm{~cm}^{-1}\right)$ for complex 1, and at $640 \mathrm{~nm}\left(\varepsilon=280 \mathrm{~L} \mathrm{~mol}^{-1} \mathrm{~cm}^{-1}\right)$ and $408 \mathrm{~nm}\left(\varepsilon=2,620 \mathrm{~L} \mathrm{~mol}^{-1} \mathrm{~cm}^{-1}\right)$ for complex 2 . The low molar extinction coefficients presented by the lower energy bands classify them as typical ligand field transitions in the $\mathrm{Cu}^{\mathrm{II}}$ centers. ${ }^{47}$ The higher energy bands can be assigned to ligand-to-metal charge transfer transitions (LMCT) from the phenoxo bridges to the $\mathrm{Cu}^{\mathrm{II}}$ ions, as proposed for other phenolate-coordinated $\mathrm{Cu}^{\mathrm{II}}$ complexes. ${ }^{24,40,46,48}$ A slight batochromic shift is observed for complex $\mathbf{2}$ when compared to complex $\mathbf{1}$. As observed before for cobalt(III) complexes with these same ligands ${ }^{49}$ this shift is a consequence of substitution of an imidazole by a pyridine ring in the ligand scaffold. In fact, we have also observed this behavior in other systems and assigned it to the greater basicity of 1-methylimidazole group compared to pyridine. ${ }^{49,50}$ Finally, electronic spectroscopy has been used to infer the geometry adopted by $\mathrm{Cu}^{\mathrm{II}}$ complexes in solution. ${ }^{48}$ Based on the similarities of the spectral data presented by complexes $\mathbf{1}$ and $\mathbf{2}$ we can conclude that they might present the same kind of geometry. The very broad shape of the spectra in the range of the low energy band makes a precise geometry attribution difficult, but points out to a distorted octahedron, ${ }^{47}$ which suggests interaction of metal centers with solvent molecules.

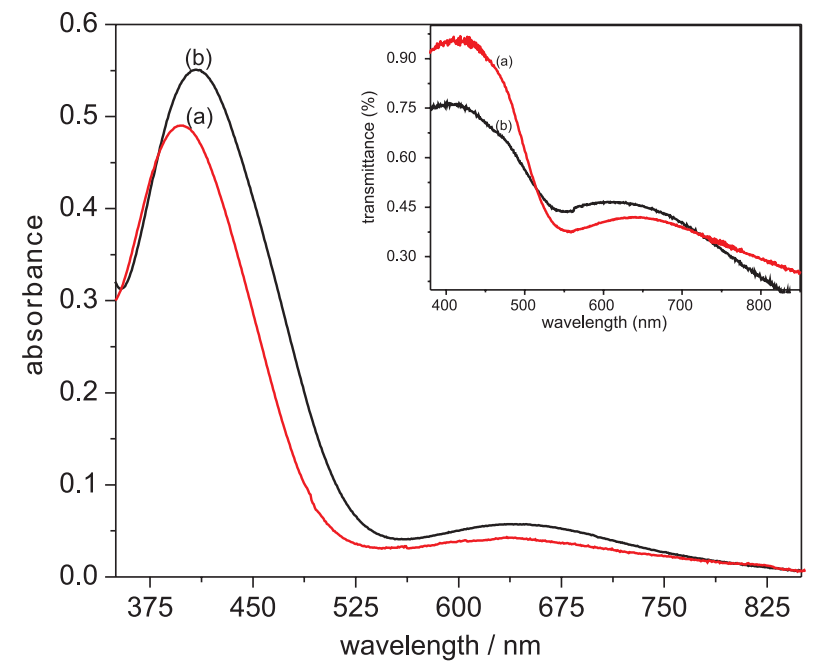

Figure 3. Electronic spectra of acetonitrile solutions of complexes 1 (line a, $\mathrm{C}=1.5 \times 10^{-4} \mathrm{~mol} \mathrm{~L}^{-1}$ ) and $\mathbf{2}$ (line $\mathrm{b}, \mathrm{C}=2.1 \times 10^{-4} \mathrm{~mol} \mathrm{~L}^{-1}$ ) and diffuse reflectance spectra (inset) of $\mathbf{1}$ (line a) and $\mathbf{2}$ (line b) in $\mathrm{KBr}$.

EPR spectroscopy was used to give some insight on this issue. X-band spectra of complexes $\mathbf{1}$ and $\mathbf{2}$ were collected in frozen ethanol solutions at $77 \mathrm{~K}$. Using the WINEPR SimFonia ${ }^{51}$ program, the experimental data were simulated; both experimental and simulated spectra are presented in Figure 4. The following parameters were determined: $\mathrm{g}_{\perp}=2.068, \mathrm{~g}_{/ /}=2.268, \mathrm{~A}_{\perp}=20 \times 10^{-4} \mathrm{~cm}^{-1}, \mathrm{~A}_{/ /}=175 \times 10^{-4} \mathrm{~cm}^{-1}$ and $\mathrm{g}_{/ /} / \mathrm{A}_{/ /}=129 \mathrm{~cm}$ (for complex 1), and $\mathrm{g}_{\perp}=2.0590$, $\mathrm{g}_{/ /}=2.261, \mathrm{~A}_{\perp}=20 \times 10^{-4} \mathrm{~cm}^{-1}, \mathrm{~A}_{/ /}=182 \times 10^{-4} \mathrm{~cm}^{-1}$ and $\mathrm{g}_{/ /} / \mathrm{A}_{/ /}=125 \mathrm{~cm}$ (for complex 2$)$. The frozen solution spectra of both complexes (Figure 4) are typically axial, presenting four well-defined lines around $\mathrm{g}=2$, with $\mathrm{g}_{/ /}>\mathrm{g}_{\perp}>2.0$ and $\mathrm{A}_{\|}>\mathrm{A}_{\perp}$. These features are characteristic of elongated octahedral, square-pyramidal or square-planar geometries, ${ }^{52}$ and have been observed for other binuclear $\mathrm{Cu}^{\mathrm{II}}$ complexes with two phenoxide bridges ${ }^{46,53}$ The empirical $\mathrm{g}_{/ /} / \mathrm{A}_{/ /}$ratio can be employed to estimate the geometry distortion around $\mathrm{Cu}^{\mathrm{II}}$ centers, and values in the range of 105 to $135 \mathrm{~cm}$ are attributed to square-planar or octahedral (with tetragonal distortion) geometries. ${ }^{54,55}$ Considering the electronic spectroscopy data and the values observed for complexes 1 $\left(\mathrm{g}_{/ /} / \mathrm{A}_{/ /}=129 \mathrm{~cm}\right)$ and $\mathbf{2}\left(\mathrm{g}_{/ /} / \mathrm{A}_{/ /}=125 \mathrm{~cm}\right)$, it is possible to infer that both complexes present interactions with solvent molecules in the axial positions. Additionally, the $\mathrm{g}_{\|} / \mathrm{A}_{/}$ ratio also provides evidence on the degree of covalency 
in the metal-ligand bond. ${ }^{21,55}$ Addison and Sakaguchi ${ }^{55}$ reported that the replacement of "hard" by "soft" donor atoms around $\mathrm{Cu}^{\text {II }}$ centers results in a decrease of $g_{/ /}$and consequently a decrease in the $\mathrm{g}_{/ /} / \mathrm{A}_{/ /}$ratio. This fact is interpreted as an increase in the electron delocalization away from the metal center, or an increase in covalency. For complexes $\mathbf{1}$ and $\mathbf{2}$, the $\mathrm{g}_{/ /}$values are very similar, but an increase in $\mathrm{A}_{/ /}$is observed when the softer base imidazole (complex 1) is replaced by pyridine (complex 2), which results in the decrease of the $\mathrm{g}_{/ /} / \mathrm{A}_{/ /}$ratio. This fact suggests a slight increase of the ligand field strength around the metal center for complex $\mathbf{2}$ compared to complex $\mathbf{1}$. In fact, as imidazole is a better $\sigma$-donor than pyridine, ${ }^{19-21,23,56}$ it was expected that HL1 presented higher ligand field strength than HL2, which is exactly the opposite behavior of the observed here.

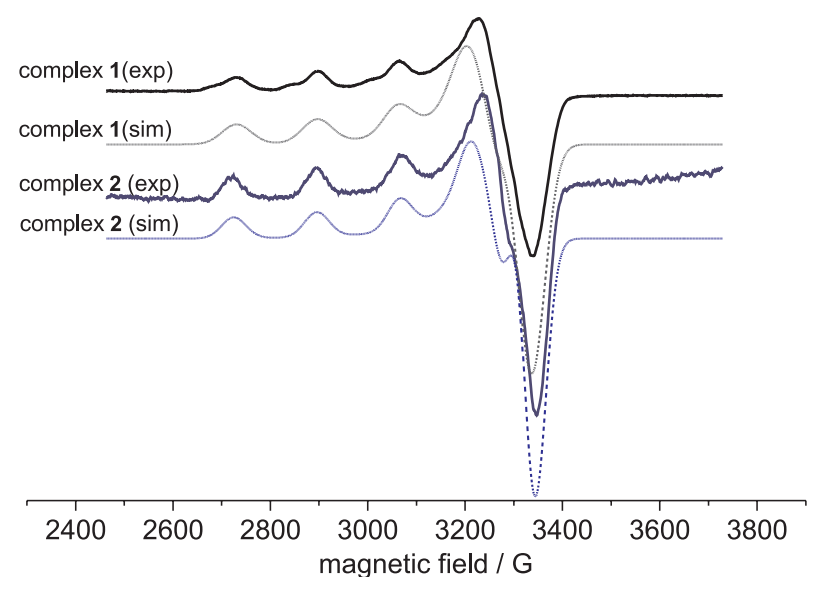

Figure 4. X-band experimental ( - ) and simulated (........) EPR spectra for complexes $\mathbf{1}$ (black) and $\mathbf{2}$ (blue/gray), in frozen ethanol solutions at $77 \mathrm{~K}$.

\section{Cyclic voltammetry studies}

The cyclic voltammograms for complex $\mathbf{1}$ in acetonitrile solution (Figure S1) do not undergo significant variation upon several scan rate measurements, presenting a broad irreversible peak at $-315 \mathrm{mV} v s$. NHE (normal hydrogen electrode). Considering that the coordination environments around the $\mathrm{Cu}^{\mathrm{II}}$ ions are identical, their reduction is expected to occur at very similar potentials, which can explain the broadening of the peak and allow us to consider it as a $\mathrm{Cu}^{\mathrm{II}} \mathrm{Cu}^{\mathrm{II}} \rightarrow \mathrm{Cu}^{\mathrm{I}} \mathrm{Cu}^{\mathrm{I}}$ process. ${ }^{20}$ This irreversibility indicates that HL1 might not be able to stabilize the reduced complex state leading it to break down (EC process). In contrast, complex 2 presents a redox activity dependent on the scan rate. As shown in Figure 5, from 50 and $100 \mathrm{mV} \mathrm{s}^{-1}$, an irreversible wave is observed at $-340 \mathrm{mV} v s$. NHE that is also tentatively attributed to the $\mathrm{Cu}^{\mathrm{II}} \mathrm{Cu}^{\mathrm{II}} \rightarrow \mathrm{Cu}^{\mathrm{I}} \mathrm{Cu}^{\mathrm{I}}$ process. The more negative value observed for complex $\mathbf{2}$ compared to complex 1 suggests that HL2 acts as a better electron donor than HL1, despite the expected behavior based on the $\sigma$-donor ability of imidazole and pyridine groups. As reported before, ${ }^{49}$ it is probably related to the LUMO features of these complexes.

When cyclic voltammograms of complex $\mathbf{2}$ are recorded at higher scan rates (125 to $250 \mathrm{mV} \mathrm{s}^{-1}$ ), an enhancement of the system reversibility is observed $\left(125 \mathrm{mV} \mathrm{s}^{-1}\right.$ : $\mathrm{E}_{1 / 2}=-332 \mathrm{mV} v s$. NHE, $\Delta \mathrm{E}_{\mathrm{p}}=125 \mathrm{mV} ; 200 \mathrm{mV} \mathrm{s}^{-1}$ : $\mathrm{E}_{1 / 2}=-328 \mathrm{mV}$ vs. NHE, $\Delta \mathrm{E}_{\mathrm{p}}=135 \mathrm{mV} ; 250 \mathrm{mV} \mathrm{s}{ }^{-1}$ : $\mathrm{E}_{1 / 2}=-323 \mathrm{mV}$ vs. NHE, $\Delta \mathrm{E}_{\mathrm{p}}=155 \mathrm{mV}$ ). This behavior suggests that, at least on the time scale of the measurements, the complex scaffold is maintained after reduction, and so a quasi-reversible process is detected. This fact can tentatively be rationalized in terms of the better $\pi$-acceptor properties of the pyridine ring which, by withdrawing electron density from the metal center after reduction, stabilizes the $\mathrm{Cu}^{\mathrm{I}} \mathrm{Cu}^{\mathrm{I}}$ species under the time scale of the experiments.

\section{Potentiometric titration}

In order to examine the $\mathrm{p} K_{\mathrm{a}}$ of water molecules coordinated to the metal centers, potentiometric studies

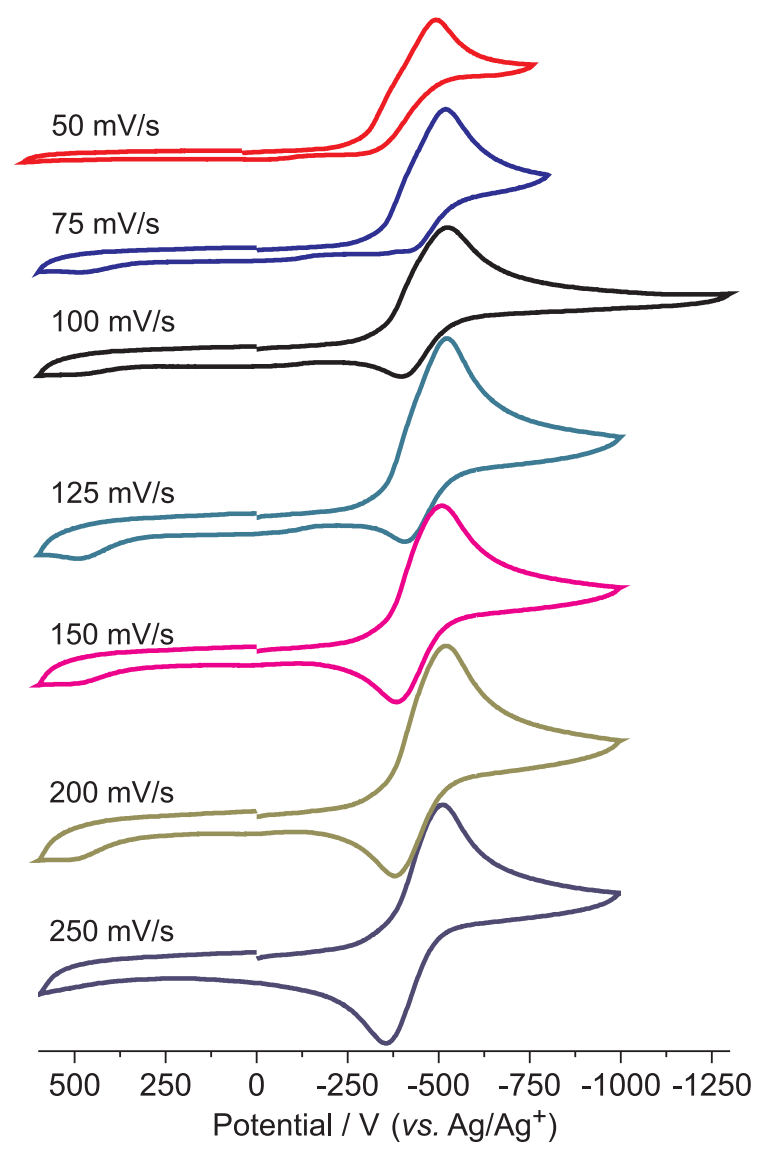

Figure 5. Cyclic voltammograms of complex $\mathbf{2}$ in methanol at different scan rates. 
were performed in acetonitrile/water mixture $(1: 1 \mathrm{v} / \mathrm{v})$. As can be seen in Figure 6, two $\mathrm{p} K_{\mathrm{a}}$ values were observed for both complexes: for complex $\mathbf{1}, \mathrm{p} K_{\mathrm{a} 1}=10.32$ and $\mathrm{p} K_{\mathrm{a} 2}=11.36$, and for complex $2, \mathrm{p} K_{\mathrm{a} 1}=10.25$ and $\mathrm{p} K_{\mathrm{a} 2}=11.27$.
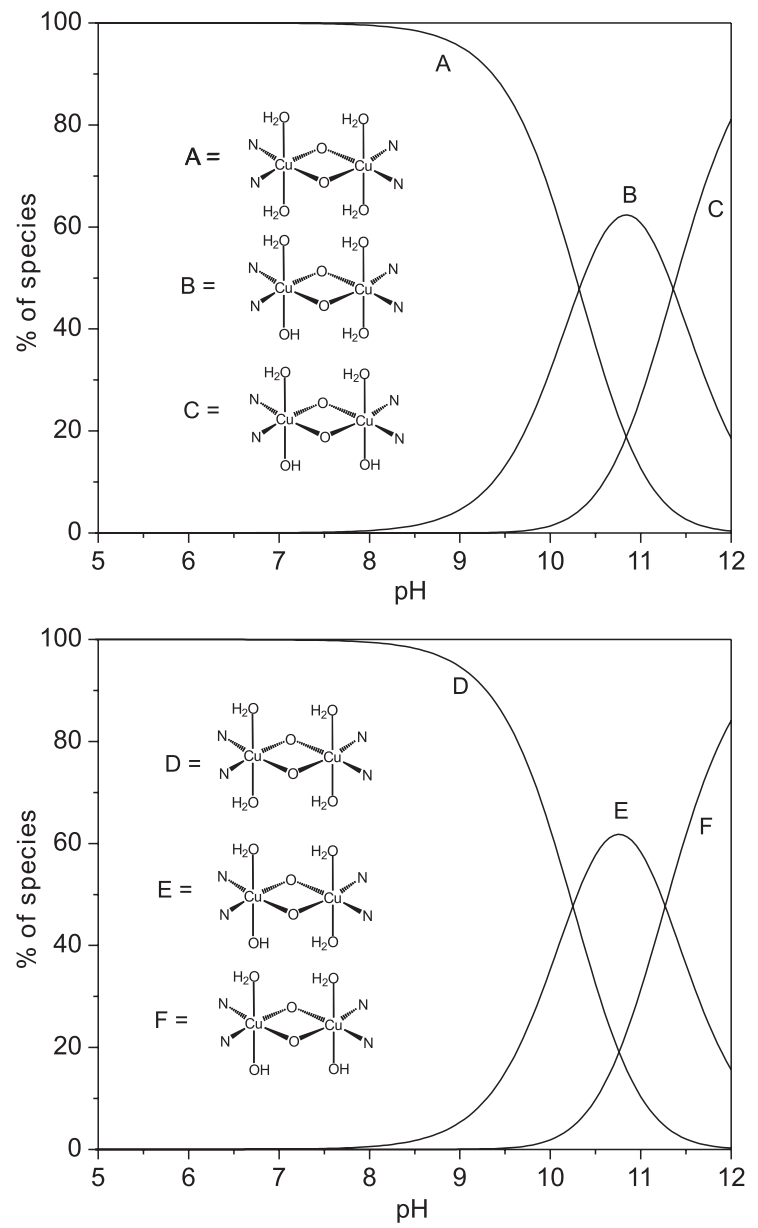

Figure 6. Diagram of species distribution for complexes $\mathbf{1}$ (up) and $\mathbf{2}$ (down).

Comparison of these results with those reported for other copper complexes in which the water molecules are considered completely coordinated to the metal center $\left(\mathrm{p} K_{\mathrm{a}} c a .8\right),{ }^{19,36,40}$ reveals that these $\mathrm{p} K_{\mathrm{a}}$ values are much higher. This fact can be tentatively explained by the existence of a weak metal-water interaction, as observed in the crystal structure of complex $\mathbf{1}$, in which the water molecule is $2.899 \AA$ away from the $\mathrm{Cu}(02)$ center. In fact, a strong Jahn-Teller effect associated with the donating ability of the phenolate groups may weaken the $\mathrm{Cu}-\mathrm{O}_{\mathrm{w}}$ bond, not permitting a significant polarization on the $\mathrm{O}-\mathrm{H}$ bond of the closest water molecule and raising its $\mathrm{p} K_{\mathrm{a}}$. It is worth to mention that the phenolate protonation constants could not be determined, probably because these groups are coordinated in a bridge mode and have very low $\mathrm{p} K_{\mathrm{a}}$.

\section{Theoretical calculations}

As mentioned earlier, the EPR and the voltammetric data obtained for complexes $\mathbf{1}$ and $\mathbf{2}$ present an inverse behavior of that expected considering only the substitution of a pyridine by an imidazole group in the ligand scaffold. As previously reported, ${ }^{49}$ this might be correlated to the features of the complexes frontier orbitals. Since the crystal structure of complex 1 revealed that the chloride anions and the water molecules are only interacting with the metal center, the geometry optimizations were carried out without them. As shown in Table 2, a good agreement was achieved between the experimental (X-ray) and the theoretical results for complex 1 and, then, the same approach was used to predict the geometry of complex 2 . Figures 7 and 8 show the optimized geometries and the graphical representations of the frontier orbitals for complexes $\mathbf{1}$ and $\mathbf{2}$, respectively.

For complex 1, the HOMO (highest occupied molecular orbital) representation shows a small participation of the nitrogen atoms of the secondary amine and a strong contribution of both phenolate bridges. On the other hand, the LUMO has the participation of the nitrogen atoms of the secondary amine and the imidazole, the phenolate groups and the $\mathrm{d}_{x^{2}-y^{2}}$ orbital of the Cu center. For complex 2, the HOMO presents high similarity with that of complex $\mathbf{1}$, and shows a small participation of the amine nitrogen atoms and a large participation of the phenolate groups. However, the LUMO of complex $\mathbf{2}$ has strong contribution of the two pyridine rings. As the HOMO of both complexes are quite similar, the behavior observed for complexes $\mathbf{1}$ and $\mathbf{2}$ might be related to the different atomic contributions to the LUMO. While the LUMO of complex $\mathbf{1}$ is composed by the contribution of several atoms and is delocalized all over

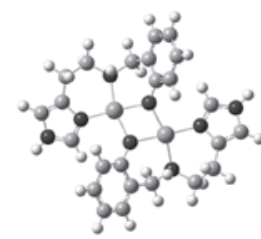

a)

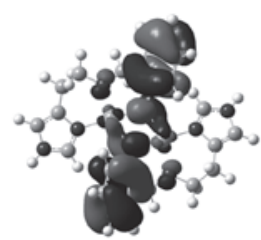

b)

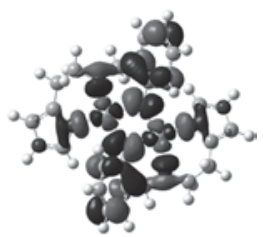

c)
Figure 7. (a) Geometry optimization, (b) HOMO and (c) LUMO for complex 1.

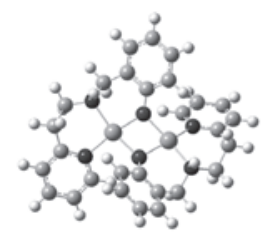

a)

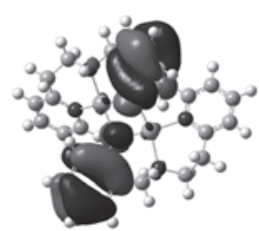

b)

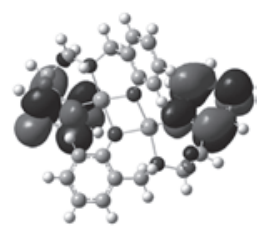

c)
Figure 8. (a) Geometry optimization, (b) HOMO and (c) LUMO for complex 2 . 
the molecule, in complex $\mathbf{2}$ it has mainly the involvement of the pyridine rings and is localized over these groups. This fact can explain the more negative potential observed for complex $\mathbf{2}$ compared to complex $\mathbf{1}$, since the increase of electron density due to the reduction process might be more easily transferred to the LUMO of complex $\mathbf{1}$ than to the LUMO of complex 2.

\section{Reactivity}

\section{Cyclohexane oxidation}

Since our intention is to develop new catalysts for oxidative processes, and alkane oxidations have great industrial interest, ${ }^{58,59}$ the cyclohexane oxidation was investigated using hydrogen peroxide at room temperature. Complexes $\mathbf{1}$ and $\mathbf{2}$ lead to low overall conversion values of 6.34 and $7.15 \%$, respectively. For complex 1, only cyclohexanol $(\mathrm{Cy}-\mathrm{OH})$ and cyclohexanone $(\mathrm{Cy}=\mathrm{O})$ were isolated as reaction products, with selectivities of $68.1 \%$ for $\mathrm{Cy}-\mathrm{OH}$ and $31.9 \%$ for $\mathrm{Cy}=\mathrm{O}$, and turnover number of 70 . For complex 2, the formation of $31.9 \%$ of $\mathrm{Cy}-\mathrm{OH}, 29 \%$ of $\mathrm{Cy}=\mathrm{O}$ and $32 \%$ of $\mathrm{Cy}-\mathrm{OOH}$ (cyclohexylhydroperoxide) was observed, and turnover number of 78. Comparing these values with other $\mathrm{Cu}^{\text {II }}$ complexes presenting vacant positions on the metal coordination sphere, the overall yields are fairly lower. ${ }^{60,61}$ This fact may be explained by the non-coplanarity of the central square-plane core and the ligand aromatic rings, which can make difficult the substrate approach, even though both complexes (1 and $\mathbf{2}$ ) present two vacant positions per $\mathrm{Cu}^{\mathrm{II}}$ center.

\section{Catechol oxidation}

The most widely employed substrate to investigate the catecholase activity of model complexes is 3,5-ditert-butylcatechol (3,5-dtbc). It is due to its low redox potential that facilitates the oxidation to quinone, and the presence of bulky substituents that prevents further oxidation reactions. ${ }^{62}$

The $\mathrm{pH}$ dependence of the catecholase activities promoted by complexes $\mathbf{1}$ and $\mathbf{2}$ was investigated in a range (5.5 to 10 ) that includes the optimal $\mathrm{pH}$ activity range observed for the enzyme. ${ }^{15}$ The plots of $\mathrm{v}_{0}$ (initial rate) vs. $\mathrm{pH}$ (Figure 9 for complex 1, and S2 for complex 2) show sigmoid-shape profiles and reveal $\mathrm{p} K_{\mathrm{a}}$ values of 9.1

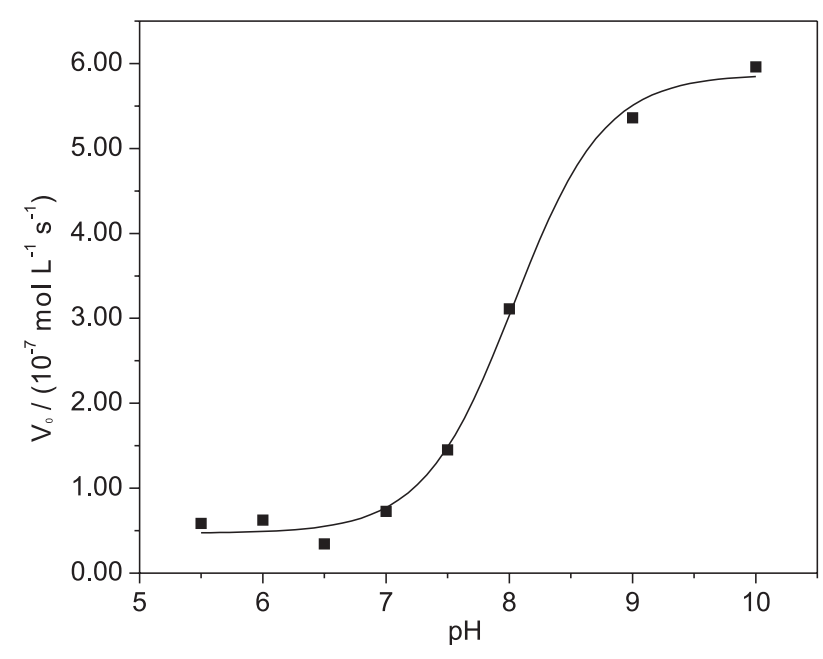

Figure 9. $\mathrm{pH}$ dependence for the oxidation of 3,5-dtbc catalyzed by complex 1, in methanol/water $(30: 1 \mathrm{v} / \mathrm{v})$ solution. Experimental conditions: $[1]_{\text {final }} 2.4 \times 10^{-5} \mathrm{~mol} \mathrm{~L}^{-1},[3,5-\mathrm{dtbc}]_{\text {final }} 5 \times 10^{-3} \mathrm{~mol} \mathrm{~L}^{-1}$, [buffer $]_{\text {final }} 3 \times 10^{-3} \mathrm{~mol} \mathrm{~L}^{-1}$, at $25^{\circ} \mathrm{C}$.

for $\mathbf{1}$ and 8.0 for complex 2, which are the kinetic $\mathrm{p} K_{\mathrm{a}}$. The difference between these values and those obtained by potentiometric titration can be explained by the fact that the kinetic $p K_{a}$ represents the water molecules deprotonation in the presence of substrate. In addition, the potentiometric $\mathrm{p} K_{\mathrm{a}}$ was determined in $\mathrm{CH}_{3} \mathrm{CN} / \mathrm{H}_{2} \mathrm{O}$ $(1: 1 \mathrm{v} / \mathrm{v})$ solution and the reactivity experiments were carried out in methanol. Based on the $\mathrm{p} K$ a values, the active species for $\mathbf{1}$ and $\mathbf{2}$ can be assigned to the aquahydroxo complex..$^{14,62-64}$ The substrate dependence was carried out at $\mathrm{pH}$ 9, and a Michaelis-Menten profile was obtained (Figure 10 for complex 1, and Figure S3 for complex 2). The parameters obtained by a non-linear fit are presented in Table 3. The values for complexes $\mathbf{1}$ and 2 indicate that they are very efficient compared to other complexes in the literature. ${ }^{35,64,65}$ The kinetic efficiency $\left(k_{\text {cat }} / K_{\mathrm{M}}\right)$ shows that complex 2 is approximately 10 times more active than complex 1 . Usually, the catecholase activity of model complexes is largely attributed to the distance $\mathrm{Cu} \cdots \mathrm{Cu}$, but other effects such as redox potentials, neighboring groups, and the individual coordination spheres can play important roles. ${ }^{66}$ For complexes $\mathbf{1}$ and $\mathbf{2}$, the $\mathrm{Cu}$... Cu distances are very similar (Table 2) and may not be the reason for their different activities. Since the first step in the proposed mechanism is the oxidation of one substrate molecule coupled to a two-electron reduction of

Table 3. Kinetic parameters for complexes $\mathbf{1}$ and $\mathbf{2}$

\begin{tabular}{lccccc}
\hline Complex & $K_{\text {cat }} / K_{\mathrm{M}}\left(\mathrm{mol} \mathrm{L}^{-1} \mathrm{~s}^{-1}\right)$ & $V_{\max }\left(\mathrm{mol} \mathrm{L}^{-1} \mathrm{~s}^{-1}\right)$ & $K_{\mathrm{M}}\left(\mathrm{mol}^{-1} \mathrm{~L}\right)$ & $K_{\text {cat }}\left(\mathrm{s}^{-1}\right)$ & $K_{\text {ass }}$ \\
\hline $\mathbf{1}$ & 10 & $1.84 \times 10^{-6}$ & $7.72 \times 10^{-3}$ & $7.69 \times 10^{-2}$ & 129 \\
$\mathbf{2}$ & 92 & $1.88 \times 10^{-6}$ & $0.86 \times 10^{-3}$ & $7.85 \times 10^{-2}$ & 1162 \\
\hline
\end{tabular}




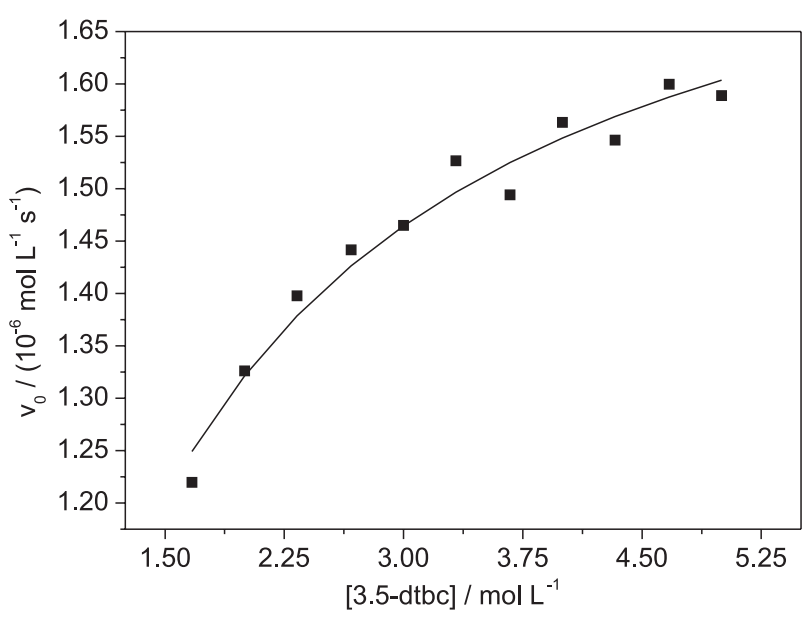

Figure 10. Dependence of the reaction rates on the 3,5-dtbc concentration for the oxidation reaction catalyzed by complex 1, in methanol/water (30:1 v/v) mixture solution. Experimental conditions: $[1]_{\text {final }} 2.4 \times 10^{-5} \mathrm{~mol} \mathrm{~L}^{-1}$, $[3,5-\mathrm{dtbc}]_{\text {final }} 1.6-5.0 \times 10^{-3} \mathrm{~mol} \mathrm{~L}^{-1},[\text { buffer }]_{\text {final }} 3 \times 10^{-3} \mathrm{~mol} \mathrm{~L}^{-1}, \mathrm{pH} 9(\mathrm{CHES}$ buffer), at $25^{\circ} \mathrm{C}$.

the active site, ${ }^{67}$ it was expected that complex 1 presented higher activity than complex $\mathbf{2}$, which has a more negative reduction potential, but this kind of correlation has been questioned. ${ }^{66}$

The non-reversibility shown in the voltammograms of complex 1 indicates that, after reduction, the complex integrity is not maintained in solution and this can be a reason of its lower reactivity. On the other hand, the reversibility shown by complex 2 at high scan rates shows that this complex does not decompose as fast as complex $\mathbf{1}$ after reduction, leading to its higher reactivity.

\section{Conclusions}

The $\mathrm{Cu}^{\mathrm{II}}$ binuclear complexes $\mathbf{1}$ and $\mathbf{2}$ are reactive in the cyclohexane oxidation, with selectivity close to $70 \%$ for the formation of cyclohexanol (for complex 1), but with conversion values low for both complexes. This low hydrocarbon oxidation activity can be attributed to steric hindrance effects produced by the non-coplanar aromatic rings of the ligand scaffold. It seems that the access of the hydrocarbon molecule to the binuclear active center is a determinant step in the mechanism of this process. As mimetic for catecholase activity, both complexes were very efficient, with complex 2 being approximately 10 times more effective than complex $\mathbf{1}$. These high efficiencies indicate that the pyridine ligand is capable to stabilize an intermediate $\mathrm{Cu}^{\mathrm{I}} \mathrm{Cu}^{\mathrm{I}}$ center, which is proposed to be formed in this process, avoiding the breaking down of the complex. This is corroborated by the strong participation of pyridine in the LUMO of complex $\mathbf{2}$, which can help to accommodate the additional negative charge when the complex is reduced from $\mathrm{Cu}^{\mathrm{II}} \mathrm{Cu}^{\mathrm{II}}$ to $\mathrm{Cu}^{\mathrm{I}} \mathrm{Cu}^{\mathrm{I}}$.

\section{Supplementary Information}

Crystallographic data have been deposited with the Cambridge Crystallographic Data Centre (deposition number CCDC 749493). Copies of the data can be obtained, free of charge, via www.ccdc.cam.ac.uk/conts/retrieving.html, or by request to CCDC, 12 Union Road, Cambridge CB2 1EZ, UK (fax 44-1223-336033 or e-mail: deposit@ccdc. cam.ac.uk). Tables with torsion angles and hydrogen bond distances for complex 1, Tables S1 and S4, and Figures S1 to $\mathrm{S} 3$ are presented as supplementary information, available free of charge at http://jbcs.sbq.org.br, as PDF file.

\section{Acknowledgments}

Authors are grateful for the facilities of the LDRX Laboratory (Laboratório de Difração de Raios X at UFF), LABEPR (Laboratório Regional Sul de EPR at UFPR), Prof. Octavio A. C. Antunes (in memorian), and grants from CAPES, CNPq and FAPERJ.

\section{References}

1. Julémon, M. In Handbook of Detergents, Part A: Properties; Broze, G. ed., Marcel Dekker, Inc: New York, 1999, p. 631.

2. Emmanuel, J.; Non-Incineration Medical Waste Treatment Technologies, Health Care without Harm: Washington, 2001, p. 61.

3. Tarchitzky, J.; Chen, Y. In Handbook of Detergents, Part B: Environmental Impact; Zoller, U. ed., Marcel Dekker: New York, 2004, p. 645.

4. Sippola, V. O.; Krause, A. O. I.; Catal. Today 2005, 100, 237.

5. Torres, E.; Bustos-Jaimes, I.; Le Borgne, S.; Appl. Cat., B 2003, $46,1$.

6. Durán, N.; Esposito, E.; Appl. Cat., B 2000, $28,83$.

7. Chiacchierini, E.; Restuccia, D.; Vini, G.; Food Sci. Technol. Int. 2004, 10, 373.

8. Ensuncho, L.; Alvarez-Cuenca, M.; Legge, R. L.; Bioprocess Biosyst. Eng. 2005, 27, 185.

9. Seetharam, G. B.; Saville, B. A.; Water Res. 2003, 37, 436.

10. Gerdemann, C.; Eicken, C.; Krebs, B.; Acc. Chem. Res. 2002, 35,183 .

11. Fusetti, F.; Schröter, K. H.; Steiner, R. A.; van Noort, P. I.; Pijning, T.; Rozeboom, H. J.; Kalk, K. H.; Egmond, M. R.; Dijkstra, B. W.; Structure 2002, 10, 259.

12. Dunwell, J. M.; Purvis, A.; Khuri, S.; Phytochemistry 2004, 65, 7.

13. Witayakran, S.; Ragauskas, A. J.; Adv. Synth. Catal. 2009, 351, 1187.

14. Klabunde, T.; Eicken, C.; Sacchettini, J. C.; Krebs, B.; Nat. Struct. Biol. 1998, 5, 1084.

15. Hildén, K.; Hakala, T. K.; Lundell, T.; Biotechnol. Lett. 2009 , 31, 1117. 
16. Alamsetti, S. K.; Mannam, S.; Mutupandi, P.; Sekar, G.; Chem. Eur. J. 2009, 15, 1086.

17. Korpi, H.; Lahtinen, P.; Sippola, V.; Krause, O.; Leskelä, M.; Repo, T.; Appl. Cat., A 2004, 268, 199.

18. Scarpellini, M.; Neves, A.; Bortoluzzi, A. J.; Joussef, A. C.; Acta Crystallogr., Sect. C: Cryst. Struct. Commun. 2001, C57, 356.

19. Scarpellini, M.; Neves, A.; Bortoluzzi, A. J.; Szpoganicz, B.; Zucco, C.; Drago, V.; Mangrich, A. S.; Ortiz, W. A.; Passos, W. A. C.; Hörner, R.; Terenzi, H.; Silva, R. A. N.; Oliveira, M. C. B.; Inorg. Chem. 2003, 42, 8353.

20. Scarpellini, M.; Neves, A.; Castellano, E. E.; Franco, D. W.; J. Mol. Struct. 2004, 694, 193.

21. Scarpellini, M.; Neves, A.; Castellano, E. E.; Almeida, E. F.; Franco, D. W.; Polyhedron 2004, 23, 511.

22. Oliveira, M. C. B.; Mazera, D.; Scarpellini, M.; Severino, P. C.; Neves, A.; Hernán. T.; Inorg. Chem. 2009, 48, 2711.

23. Scarpellini, M.; Neves, A.; Bortoluzzi, A. J.; Vencato, I.; Drago, V.; Ortiz, W. A.; Zucco, C.; J. Chem. Soc., Dalton Trans. 2001, 2616.

24. Yajima, T.; Shimazaki, Y.; Ishigami, N.; Odani, A.; Yamauchi, O.; Inorg. Chim. Acta 2002, 337, 193.

25. Gagné, R.; Koval, C.; Licenski, G.; Inorg. Chem. 1980, 19, 2854.

26. Geary, W. J.; Coord. Chem. Rev. 1971, 7, 81.

27. Martell, A. E.; Motekaitis. R. J.; Determination of Stability Constants, 2nd ed.; VHC Publishers: Weinheim, Germany, 1992.

28. Duisenberg, A. J. M.; J. Appl. Cryst. 1992, 25, 92.

29. Duisenberg, A. J. M.; Kroon-Batenburg, L. M. J.; Schreurs, A. M. M.; J. Appl. Cryst. 2003, 36, 220.

30. SADABS Bruker Analytical X-ray Systems, Inc., Madison WI, 1997.

31. Sheldrick, G. M.; Schneider, T. R.; Methods Enzymol. 1997, $277,319$.

32. Johnson, C. K. In Crystallographic Computing; Ahmed, F. R. ed., Copenhagen: Munksgaard, 1970, pp. 207-219.

33. Fernández, T. L.; Souza, E. T.; Visentin, L. C.; Santos, J. V.; Mangrich, A. S.; Faria, R. B.; Antunes, O. A. C.; Scarpellini, M.; J. Inorg. Biochem. 2009, 103, 474.

34. Côrtes, C. E. S; Faria, R. B.; Inorg. Chem. 2004, 43, 1395.

35. Peralta, R. A.; Neves A.; Bortoluzzi, A. J.; Anjos, A.; Xavier, F. R.; Szpoganicz, B.; Terenzi, H.; Oliveira M. C. B.; Castellano, E.E.; Friedermann, G. R.; Mangrich, A. S.; Novak, M. A.; J. Inorg. Biochem. 2006, 100, 992.

36. Signorella, S.; Rompel, A.; Bült-Karentzopoulos, K.; Krebs, B.; Pecoraro, V. L. Tuchagues, J.-P.; Inorg. Chem. 2007, 46, 10864

37. Frisch, M. J.; Trucks, G. W.; Schlegel, H. B.; Scuseria, G. E.; Robb, M. A.; Cheeseman, J. R.; Montgomery, Jr., J. A.; Vreven, T.; Kudin, K. N.; Burant, J. C.; Millam, J. M.; Iyengar, S. S.;
Tomasi, J.; Barone, V.; Mennucci, B.; Cossi, M.; Scalmani, G.; Rega, N.; Petersson, G. A.; Nakatsuji, H.; Hada, M.; Ehara, M.; Toyota, K.; Fukuda, R.; Hasegawa, J.; Ishida, M.; Nakajima, T.; Honda, Y.; Kitao, O.; Nakai, H.; Klene, M.; Li, X.; Knox, J. E.; Hratchian, H. P.; Cross, J. B.; Bakken, V.; Adamo, C.; Jaramillo, J.; Gomperts, R.; Stratmann, R. E.; Yazyev, O.; Austin, A. J.; Cammi, R.; Pomelli, C.; Ochterski, J. W.; Ayala, P. Y.; Morokuma, K.; Voth, G. A.; Salvador, P.; Dannenberg, J. J.; Zakrzewski, V. G.; Dapprich, S.; Daniels, A. D.; Strain, M. C.; Farkas, O.; Malick, D. K.; Rabuck, A. D.; Raghavachari, K.; Foresman, J. B.; Ortiz, J. V.; Cui, Q.; Baboul, A. G.; Clifford, S.; Cioslowski, J.; Stefanov, B. B.; Liu, G.; Liashenko, A.; Piskorz, P.; Komaromi, I.; Martin, R. L.; Fox, D. J.; Keith, T.; Al-Laham, M. A.; Peng, C. Y.; Nanayakkara, A.; Challacombe, M.; Gill, P. M. W.; Johnson, B.; Chen, W.; Wong, M. W.; Gonzalez, C.; Pople, J. A.; Gaussian 03, Revision C.02, Gaussian, Inc., Wallingford CT, 2004.

38. Nakamoto, K.; Infrared and Raman Spectra of Inorganic and Coordination Compounds, 3rd ed., John Wiley \& Sons, Inc: New York, 1977, part III, pp. 231-232, 242.

39. Farrugia, L. J.; J. Appl. Crystallogr. 1997, 30, 565.

40. Oliveira, M. C. B.; Scarpellini, M.; Neves, A.; Terenzi, H.; Bortoluzzi, A. J.; Szpoganicz, B.; Mangrich, A. S.; Inorg. Chem. 2005, 44, 921.

41. Albada, G.A.; Smeets, W.J.J.; Spelk, A.L.; Reedjik, J.; Inorg. Chim. Acta 1999, 288, 220.

42. Belle, C.; Beguin, C.; Gautier-Luneau, I.; Hamman, S.; Philouze, C.; Pierre, J. L.; Thomas F.; Torelli, S.; Inorg. Chem. 2002, 41, 479.

43. Xie, Y.; Jiang, H.; Chan, A.S.; Liu, Q.; Xu, X.; Du, C.; Zhu, Y.; Inorg. Chim. Acta 2002, 333, 138.

44. Wang, X.; Ding, J.; Ranford, J. D.; Vital, J. J.; J. App. Phys. 2003, 98, 10.

45. Kong, D.; Mao, J.; Martell, A. E.; Clearfiel, A.; Inorg. Chim. Acta 2003, 342, 260.

46. Taki, M.; Kumei, H.; Nagatomo, S.; Kitagawa, T.; Itoh, S.; Fukuzumi, S.; Inorg. Chim. Acta 2000, 300-302, 622.

47. Lever, A. B. P.; Inorganic Electronic Spectroscopy, 2nd ed., Elsevier Science Publishers B. V.: Amsterdam, 1984, pp. 553572.

48. Karlin, K.D.; Gultneh, Y.; Nicholson, T.; Zubieta, J.; Inorg. Chem. 1985, 24, 3725.

49. Souza, E. T.; Castro, L. C.; Castro, F. A. V.; Visentin, L. C.; Pinheiro, C. B.; Pereira, M. D.; Machado, S. P.; Scarpellini, M.; J. Inorg. Biochem. 2009, 103, 1355.

50. Scarpellini, M.; Casellato, A.; Bortoluzzi, A. J.; Vencato, I.; Mangrich, A. S.; Neves, A.; Machado, S. P.; J. Braz. Chem. Soc. 2006, 17, 1617.

51. Brucker EPR, WINEPR and SimFonia: post processing program and simulation software for PC-Windows, version 1.0, 1997. 
52. Hathaway, B. J.; Hodgson, P. G.; J. Inorg. Nucl. Chem. 1973, 35, 4071.

53. Kruse, T.; Weyhermüller, T.; Wieghardt, K.; Inorg. Chim. Acta 2002, 331, 81.

54. Silva, L. A.; Andrade, J. B.; Mangrich, A. S.; J. Braz. Chem. Soc. 2007, 18, 607.

55. Sakaguchi, U.; Addison, A. W.; J. Chem. Soc., Dalton Trans. 1979, 600 .

56. Scarpellini, M.; Toledo Júnior, J. C.; Neves, A.; Ellena, J.; Castellano, E. E.; Franco, D. W.; Inorg. Chim. Acta 2004, 357, 707.

57. Greatti, A.; Scarpellini, M.; Peralta, R. A.; Casellato, A.; Bortoluzzi, A. J.; Xavier, F. R.; Jovito, R.; Brito, M. A.; Szpoganicz, B.; Tomkowicz, Z.; Rams, M.; Haase, W.; Neves, A.; Inorg. Chem. 2008, 47, 1107.

58. Schuchardt, U.; Cardoso, D.; Sercheli, R.; Pereira, R.; Cruz, R. S.; Guerreiro, M. C.; Mandelli, D.; Spinacé, E. V.; Pires, E. L.; Appl. Catal., A 2001, 211, 1.

59. Punniyamurthy, T.; Rout, L.; Coord. Chem. Rev. 2008, 252, 134.
60. Silva, A. C.; Fernández, T. L.; Carvalho, N. M. F.; Herbst, M. H.; Bordinhão, J.; Horn Jr, A.; Wardell, J. L.; Oestreicher, E. G.; Antunes, O. A. C.; Appl. Catal., A 2007, 317, 154 and references therein.

61. Canhota, F. P.; Salomão, G. C.; Carvalho, N. M. F.; Antunes, O. A. C.; Catal. Comm. 2008, 9, 182 and references therein.

62. Rompel, A.; Fischer, H.; Meiwes, D.; Buldt-Karentzopoulos, K.; Magrini, A.; Eicken, C.; Gerdemann, C.; Krebs, B.; FEBS Lett. 1999, 103, 445.

63. Gerdmann, C.; Eicken, C.; Krebs, B.; Acc. Chem. Res. 2002, $35,183$.

64. Rey, N. A.; Neves, A.; Bortoluzzi, A.; Pich, C. T.; Terenzi, H.; Inorg. Chem. 2007, 46, 348.

65. Neves, A; Rossi, L. M.; Bortoluzzi, A.J.; Szpoganicz, B.; Wiezbicki, C.; Schwingel E.; Haase, W.; Ostrovsky, S.; Inorg. Chem. 2002, 41, 1788.

66. Relm, J.; Krebs, B.; Dalton Trans. 1997, 3793.

67. Ackermann, J., Meyer, F., Kaifer, E., Pritzkow, H.; Chem. Eur. J. 2002, 8, 247. 


\section{Binuclear $\mathrm{Cu}^{\mathrm{II}}$ Complexes as Catalysts for Hydrocarbon and Catechol Oxidation Reactions with Hydrogen Peroxide and Molecular Oxygen}

\section{Luciana R. Martins, ${ }^{a}$ Elizabeth T. Souza, ${ }^{a}$ Tatiana L. Fernandez, ${ }^{a}$ Bernardo de Souza, ${ }^{b}$ Sílvio Rachinski, ${ }^{c}$ Carlos B. Pinheiro, ${ }^{d}$ Roberto B. Faria,${ }^{a}$ Annelise Casellato, ${ }^{a}$ Sérgio P. Machado, ${ }^{a}$ Antonio S. Mangrich ${ }^{*, c}$ and Marciela Scarpellini ${ }^{*, a}$}

${ }^{a}$ Departamento de Química Inorgânica, Instituto de Química, Universidade Federal do Rio de Janeiro, 21945-970 Rio de Janeiro - RJ, Brazil

${ }^{b}$ Departamento de Química, Universidade Federal de Santa Catarina, 88040-900 Florianópolis - SC, Brazil

${ }^{c}$ Departamento de Química, Universidade Federal do Paraná, 81531-970 Curitiba - PR, Brazil

${ }^{d}$ Departamento de Física, Instituto de Ciências Exatas, Universidade Federal de Minas Gerais, 31270-901 Belo Horizonte - MG, Brazil

Table S1. Experimental and theoretical infrared data $\left(\mathrm{cm}^{-1}\right)$ for HL1, HL2 and complexes 1 and 2

\begin{tabular}{lcccccccc}
\hline & \multicolumn{2}{c}{ HL1 } & \multicolumn{2}{c}{ HL2 } & \multicolumn{2}{c}{ Complex 1 } & \multicolumn{2}{c}{ Complex 2 } \\
Attribution & Exp. & Theor. & Exp. & Theor. & Exp. & Theor. & Exp. & Theor. \\
\hline$v(\mathrm{NH})_{\text {im }}$ & 3313 & 3647 & - & - & - & - & - & $3071-2958$ \\
$v(\mathrm{CH})_{\mathrm{Ar}}$ & - & - & $2928-2638$ & $3219-2977$ & $3134-3037$ & $3072-2941$ & $3072-2941$ & 3240 \\
$v(\mathrm{NH})_{\mathrm{sec}}$ & 3124 & 3498 & 3288 & 3484 & 2909 & 3240 & 3240 \\
$v(\mathrm{C}=\mathrm{N})$ & 1597 & 1539 & 1715 & 1669 & 1596 & 1610 & 1610 & 1613 \\
$v(\mathrm{C}=\mathrm{C})$ & $1574-1459$ & 1555 & $1592-1458$ & 1554 & $1596-1454$ & 1423 & 1423 & 1416 \\
$\delta(\mathrm{O}-\mathrm{H})_{\mathrm{ph}}$ & 1398 & 1381 & 1366 & 1378 & - & - & - & - \\
$v(\mathrm{C}-\mathrm{O})$ & 1277 & 1295 & 1258 & 1297 & 1275 & 1259 & 1259 & 1259 \\
$\delta(\mathrm{CH})_{\mathrm{Ar}}$ & 748 & 761 & 755 & 763 & 771 & 775 & 775 & 785 \\
$v(\mathrm{Cl}-\mathrm{O})$ & - & - & - & - & $1130-1028$ & - & - & - \\
\hline
\end{tabular}

*e-mail: mangrich@quimica.ufpr.br, marciela@iq.ufrj.br 
Table S2. Torsion angles $\left(^{\circ}\right)$ for complex 1

\begin{tabular}{|c|c|}
\hline $\mathrm{N}(10)-\mathrm{Cu}(1)-\mathrm{Cu}(2)-\mathrm{N}(12)$ & $102.0(2)$ \\
\hline $\mathrm{O}(6)-\mathrm{Cu}(1)-\mathrm{Cu}(2)-\mathrm{N}(12)$ & $-44.7(3)$ \\
\hline $\mathrm{O}(5)-\mathrm{Cu}(1)-\mathrm{Cu}(2)-\mathrm{N}(12)$ & $159.4(3)$ \\
\hline $\mathrm{N}(9)-\mathrm{Cu}(1)-\mathrm{Cu}(2)-\mathrm{N}(12)$ & $-25.5(3)$ \\
\hline $\mathrm{Cl}(3)-\mathrm{Cu}(1)-\mathrm{Cu}(2)-\mathrm{N}(12)$ & $-123.59(19)$ \\
\hline $\mathrm{N}(10)-\mathrm{Cu}(1)-\mathrm{Cu}(2)-\mathrm{O}(5)$ & $-57.3(3)$ \\
\hline $\mathrm{O}(6)-\mathrm{Cu}(1)-\mathrm{Cu}(2)-\mathrm{O}(5)$ & $156.0(3)$ \\
\hline $\mathrm{N}(9)-\mathrm{Cu}(1)-\mathrm{Cu}(2)-\mathrm{O}(5)$ & $175.1(3)$ \\
\hline $\mathrm{Cl}(3)-\mathrm{Cu}(1)-\mathrm{Cu}(2)-\mathrm{O}(5)$ & $77.0(2)$ \\
\hline $\mathrm{N}(10)-\mathrm{Cu}(1)-\mathrm{Cu}(2)-\mathrm{O}(6)$ & 146.7(3) \\
\hline $\mathrm{O}(5)-\mathrm{Cu}(1)-\mathrm{Cu}(2)-\mathrm{O}(6)$ & $-156.0(3)$ \\
\hline $\mathrm{N}(9)-\mathrm{Cu}(1)-\mathrm{Cu}(2)-\mathrm{O}(6)$ & $19.2(3)$ \\
\hline $\mathrm{Cl}(3)-\mathrm{Cu}(1)-\mathrm{Cu}(2)-\mathrm{O}(6)$ & $-78.9(2)$ \\
\hline $\mathrm{N}(10)-\mathrm{Cu}(1)-\mathrm{Cu}(2)-\mathrm{N}(7)$ & $-44.3(3)$ \\
\hline $\mathrm{O}(6)-\mathrm{Cu}(1)-\mathrm{Cu}(2)-\mathrm{N}(7)$ & $169.0(3)$ \\
\hline $\mathrm{O}(5)-\mathrm{Cu}(1)-\mathrm{Cu}(2)-\mathrm{N}(7)$ & $13.0(3)$ \\
\hline $\mathrm{N}(9)-\mathrm{Cu}(1)-\mathrm{Cu}(2)-\mathrm{N}(7)$ & $-171.9(3)$ \\
\hline $\mathrm{Cl}(3)-\mathrm{Cu}(1)-\mathrm{Cu}(2)-\mathrm{N}(7)$ & $90.0(2)$ \\
\hline $\mathrm{N}(12)-\mathrm{Cu}(2)-\mathrm{O}(5)-\mathrm{C}(15)$ & $138.5(6)$ \\
\hline $\mathrm{O}(6)-\mathrm{Cu}(2)-\mathrm{O}(5)-\mathrm{C}(15)$ & $-155.1(5)$ \\
\hline $\mathrm{N}(7)-\mathrm{Cu}(2)-\mathrm{O}(5)-\mathrm{C}(15)$ & $18.8(5)$ \\
\hline $\mathrm{Cu}(1)-\mathrm{Cu}(2)-\mathrm{O}(5)-\mathrm{C}(15)$ & $-170.5(6)$ \\
\hline $\mathrm{N}(12)-\mathrm{Cu}(2)-\mathrm{O}(5)-\mathrm{Cu}(1)$ & $-50.9(6)$ \\
\hline $\mathrm{O}(6)-\mathrm{Cu}(2)-\mathrm{O}(5)-\mathrm{Cu}(1)$ & $15.5(2)$ \\
\hline $\mathrm{N}(7)-\mathrm{Cu}(2)-\mathrm{O}(5)-\mathrm{Cu}(1)$ & $-170.6(2)$ \\
\hline $\mathrm{N}(10)-\mathrm{Cu}(1)-\mathrm{O}(5)-\mathrm{C}(15)$ & $-57.8(5)$ \\
\hline $\mathrm{O}(6)-\mathrm{Cu}(1)-\mathrm{O}(5)-\mathrm{C}(15)$ & $154.7(5)$ \\
\hline $\mathrm{N}(9)-\mathrm{Cu}(1)-\mathrm{O}(5)-\mathrm{C}(15)$ & $150.2(10)$ \\
\hline $\mathrm{Cl}(3)-\mathrm{Cu}(1)-\mathrm{O}(5)-\mathrm{C}(15)$ & $54.5(5)$ \\
\hline $\mathrm{Cu}(2)-\mathrm{Cu}(1)-\mathrm{O}(5)-\mathrm{C}(15)$ & $170.3(6)$ \\
\hline $\mathrm{N}(10)-\mathrm{Cu}(1)-\mathrm{O}(5)-\mathrm{Cu}(2)$ & $131.9(2)$ \\
\hline $\mathrm{O}(6)-\mathrm{Cu}(1)-\mathrm{O}(5)-\mathrm{Cu}(2)$ & $-15.6(2)$ \\
\hline $\mathrm{N}(9)-\mathrm{Cu}(1)-\mathrm{O}(5)-\mathrm{Cu}(2)$ & $-20.1(13)$ \\
\hline $\mathrm{Cl}(3)-\mathrm{Cu}(1)-\mathrm{O}(5)-\mathrm{Cu}(2)$ & $-115.75(17)$ \\
\hline $\mathrm{N}(10)-\mathrm{Cu}(1)-\mathrm{O}(6)-\mathrm{C}(27)$ & $137.4(5)$ \\
\hline $\mathrm{O}(5)-\mathrm{Cu}(1)-\mathrm{O}(6)-\mathrm{C}(27)$ & $-145.9(5)$ \\
\hline $\mathrm{N}(9)-\mathrm{Cu}(1)-\mathrm{O}(6)-\mathrm{C}(27)$ & $33.3(5)$ \\
\hline
\end{tabular}

\begin{tabular}{|c|c|}
\hline $\mathrm{Cl}(3)-\mathrm{Cu}(1)-\mathrm{O}(6)-\mathrm{C}(27)$ & $-46.6(5)$ \\
\hline $\mathrm{Cu}(2)-\mathrm{Cu}(1)-\mathrm{O}(6)-\mathrm{C}(27)$ & $-161.1(6)$ \\
\hline $\mathrm{N}(10)-\mathrm{Cu}(1)-\mathrm{O}(6)-\mathrm{Cu}(2)$ & $-61.4(4)$ \\
\hline $\mathrm{O}(5)-\mathrm{Cu}(1)-\mathrm{O}(6)-\mathrm{Cu}(2)$ & $15.3(2)$ \\
\hline $\mathrm{N}(9)-\mathrm{Cu}(1)-\mathrm{O}(6)-\mathrm{Cu}(2)$ & $-165.6(2)$ \\
\hline $\mathrm{Cl}(3)-\mathrm{Cu}(1)-\mathrm{O}(6)-\mathrm{Cu}(2)$ & $114.57(18)$ \\
\hline $\mathrm{N}(12)-\mathrm{Cu}(2)-\mathrm{O}(6)-\mathrm{C}(27)$ & $-57.3(6)$ \\
\hline $\mathrm{O}(5)-\mathrm{Cu}(2)-\mathrm{O}(6)-\mathrm{C}(27)$ & $143.0(6)$ \\
\hline $\mathrm{Cu}(1)-\mathrm{Cu}(2)-\mathrm{O}(6)-\mathrm{C}(27)$ & $158.6(7)$ \\
\hline $\mathrm{N}(12)-\mathrm{Cu}(2)-\mathrm{O}(6)-\mathrm{Cu}(1)$ & $144.1(2)$ \\
\hline $\mathrm{O}(5)-\mathrm{Cu}(2)-\mathrm{O}(6)-\mathrm{Cu}(1)$ & $-15.6(2)$ \\
\hline $\mathrm{N}(12)-\mathrm{Cu}(2)-\mathrm{N}(7)-\mathrm{C}(20)$ & $-139.0(5)$ \\
\hline $\mathrm{O}(5)-\mathrm{Cu}(2)-\mathrm{N}(7)-\mathrm{C}(20)$ & 21.7(5) \\
\hline $\mathrm{Cu}(1)-\mathrm{Cu}(2)-\mathrm{N}(7)-\mathrm{C}(20)$ & $13.3(6)$ \\
\hline $\mathrm{N}(12)-\mathrm{Cu}(2)-\mathrm{N}(7)-\mathrm{C}(25)$ & $-8.3(5)$ \\
\hline $\mathrm{O}(5)-\mathrm{Cu}(2)-\mathrm{N}(7)-\mathrm{C}(25)$ & $152.4(4)$ \\
\hline $\mathrm{Cu}(1)-\mathrm{Cu}(2)-\mathrm{N}(7)-\mathrm{C}(25)$ & $144.0(4)$ \\
\hline $\mathrm{N}(10)-\mathrm{Cu}(1)-\mathrm{N}(9)-\mathrm{C}(29)$ & $-1.3(5)$ \\
\hline $\mathrm{O}(6)-\mathrm{Cu}(1)-\mathrm{N}(9)-\mathrm{C}(29)$ & $146.2(5)$ \\
\hline $\mathrm{O}(5)-\mathrm{Cu}(1)-\mathrm{N}(9)-\mathrm{C}(29)$ & $150.7(10)$ \\
\hline $\mathrm{Cl}(3)-\mathrm{Cu}(1)-\mathrm{N}(9)-\mathrm{C}(29)$ & $-111.6(5)$ \\
\hline $\mathrm{Cu}(2)-\mathrm{Cu}(1)-\mathrm{N}(9)-\mathrm{C}(29)$ & 134.1(4) \\
\hline $\mathrm{N}(10)-\mathrm{Cu}(1)-\mathrm{N}(9)-\mathrm{C}(17)$ & $-132.9(5)$ \\
\hline $\mathrm{O}(6)-\mathrm{Cu}(1)-\mathrm{N}(9)-\mathrm{C}(17)$ & $14.5(5)$ \\
\hline $\mathrm{O}(5)-\mathrm{Cu}(1)-\mathrm{N}(9)-\mathrm{C}(17)$ & $19.0(14)$ \\
\hline $\mathrm{Cl}(3)-\mathrm{Cu}(1)-\mathrm{N}(9)-\mathrm{C}(17)$ & $116.7(5)$ \\
\hline $\mathrm{Cu}(2)-\mathrm{Cu}(1)-\mathrm{N}(9)-\mathrm{C}(17)$ & $2.4(5)$ \\
\hline $\mathrm{O}(6)-\mathrm{Cu}(1)-\mathrm{N}(10)-\mathrm{C}(19)$ & $45.5(7)$ \\
\hline $\mathrm{O}(5)-\mathrm{Cu}(1)-\mathrm{N}(10)-\mathrm{C}(19)$ & $-26.2(5)$ \\
\hline $\mathrm{N}(9)-\mathrm{Cu}(1)-\mathrm{N}(10)-\mathrm{C}(19)$ & $148.8(5)$ \\
\hline $\mathrm{Cl}(3)-\mathrm{Cu}(1)-\mathrm{N}(10)-\mathrm{C}(19)$ & $-130.3(5)$ \\
\hline $\mathrm{Cu}(2)-\mathrm{Cu}(1)-\mathrm{N}(10)-\mathrm{C}(19)$ & $5.9(6)$ \\
\hline $\mathrm{O}(6)-\mathrm{Cu}(1)-\mathrm{N}(10)-\mathrm{C}(30)$ & $-119.2(5)$ \\
\hline $\mathrm{O}(5)-\mathrm{Cu}(1)-\mathrm{N}(10)-\mathrm{C}(30)$ & 169.1(5) \\
\hline $\mathrm{N}(9)-\mathrm{Cu}(1)-\mathrm{N}(10)-\mathrm{C}(30)$ & $-16.0(5)$ \\
\hline $\mathrm{Cl}(3)-\mathrm{Cu}(1)-\mathrm{N}(10)-\mathrm{C}(30)$ & $65.0(5)$ \\
\hline $\mathrm{Cu}(2)-\mathrm{Cu}(1)-\mathrm{N}(10)-\mathrm{C}(30)$ & $-158.8(4)$ \\
\hline
\end{tabular}


Table S2. Cont.

\begin{tabular}{|c|c|}
\hline $\mathrm{O}(5)-\mathrm{Cu}(2)-\mathrm{N}(12)-\mathrm{C}(16)$ & $34.1(8)$ \\
\hline $\mathrm{O}(6)-\mathrm{Cu}(2)-\mathrm{N}(12)-\mathrm{C}(16)$ & $-29.6(5)$ \\
\hline $\mathrm{N}(7)-\mathrm{Cu}(2)-\mathrm{N}(12)-\mathrm{C}(16)$ & $153.4(5)$ \\
\hline $\mathrm{Cu}(1)-\mathrm{Cu}(2)-\mathrm{N}(12)-\mathrm{C}(16)$ & $-2.8(6)$ \\
\hline $\mathrm{O}(5)-\mathrm{Cu}(2)-\mathrm{N}(12)-\mathrm{C}(13)$ & $-130.9(6)$ \\
\hline $\mathrm{O}(6)-\mathrm{Cu}(2)-\mathrm{N}(12)-\mathrm{C}(13)$ & $165.3(5)$ \\
\hline $\mathrm{N}(7)-\mathrm{Cu}(2)-\mathrm{N}(12)-\mathrm{C}(13)$ & $-11.7(5)$ \\
\hline $\mathrm{Cu}(1)-\mathrm{Cu}(2)-\mathrm{N}(12)-\mathrm{C}(13)$ & $-167.9(4)$ \\
\hline $\mathrm{C}(16)-\mathrm{N}(12)-\mathrm{C}(13)-\mathrm{C}(28)$ & $0.4(7)$ \\
\hline $\mathrm{Cu}(2)-\mathrm{N}(12)-\mathrm{C}(13)-\mathrm{C}(28)$ & $167.9(4)$ \\
\hline $\mathrm{C}(16)-\mathrm{N}(12)-\mathrm{C}(13)-\mathrm{C}(23)$ & $-176.5(5)$ \\
\hline $\mathrm{Cu}(2)-\mathrm{N}(12)-\mathrm{C}(13)-\mathrm{C}(23)$ & $-9.0(8)$ \\
\hline $\mathrm{C}(22)-\mathrm{C}(11)-\mathrm{C}(15)-\mathrm{O}(5)$ & $-178.4(6)$ \\
\hline $\mathrm{C}(22)-\mathrm{C}(11)-\mathrm{C}(15)-\mathrm{C}(21)$ & $2.2(9)$ \\
\hline $\mathrm{Cu}(2)-\mathrm{O}(5)-\mathrm{C}(15)-\mathrm{C}(11)$ & $152.7(5)$ \\
\hline $\mathrm{Cu}(1)-\mathrm{O}(5)-\mathrm{C}(15)-\mathrm{C}(11)$ & $-15.1(8)$ \\
\hline $\mathrm{Cu}(2)-\mathrm{O}(5)-\mathrm{C}(15)-\mathrm{C}(21)$ & $-27.8(8)$ \\
\hline $\mathrm{Cu}(1)-\mathrm{O}(5)-\mathrm{C}(15)-\mathrm{C}(21)$ & $164.4(4)$ \\
\hline $\mathrm{C}(13)-\mathrm{N}(12)-\mathrm{C}(16)-\mathrm{N}(8)$ & $-0.1(7)$ \\
\hline $\mathrm{Cu}(2)-\mathrm{N}(12)-\mathrm{C}(16)-\mathrm{N}(8)$ & $-167.4(4)$ \\
\hline $\mathrm{C}(28)-\mathrm{N}(8)-\mathrm{C}(16)-\mathrm{N}(12)$ & $-0.2(7)$ \\
\hline $\mathrm{C}(29)-\mathrm{N}(9)-\mathrm{C}(17)-\mathrm{C}(24)$ & $167.6(6)$ \\
\hline $\mathrm{Cu}(1)-\mathrm{N}(9)-\mathrm{C}(17)-\mathrm{C}(24)$ & $-55.7(7)$ \\
\hline $\mathrm{C}(30)-\mathrm{N}(10)-\mathrm{C}(19)-\mathrm{N}(14)$ & $0.1(7)$ \\
\hline $\mathrm{Cu}(1)-\mathrm{N}(10)-\mathrm{C}(19)-\mathrm{N}(14)$ & $-166.8(4)$ \\
\hline $\mathrm{C}(31)-\mathrm{N}(14)-\mathrm{C}(19)-\mathrm{N}(10)$ & $-0.1(7)$ \\
\hline $\mathrm{C}(25)-\mathrm{N}(7)-\mathrm{C}(20)-\mathrm{C}(21)$ & $170.3(6)$ \\
\hline $\mathrm{Cu}(2)-\mathrm{N}(7)-\mathrm{C}(20)-\mathrm{C}(21)$ & $-55.6(7)$ \\
\hline $\mathrm{C}(11)-\mathrm{C}(15)-\mathrm{C}(21)-\mathrm{C}(34)$ & $-4.1(9)$ \\
\hline $\mathrm{O}(5)-\mathrm{C}(15)-\mathrm{C}(21)-\mathrm{C}(34)$ & $176.4(5)$ \\
\hline $\mathrm{C}(11)-\mathrm{C}(15)-\mathrm{C}(21)-\mathrm{C}(20)$ & $171.5(6)$ \\
\hline $\mathrm{O}(5)-\mathrm{C}(15)-\mathrm{C}(21)-\mathrm{C}(20)$ & $-7.9(9)$ \\
\hline $\mathrm{N}(7)-\mathrm{C}(20)-\mathrm{C}(21)-\mathrm{C}(34)$ & $-131.1(6)$ \\
\hline $\mathrm{N}(7)-\mathrm{C}(20)-\mathrm{C}(21)-\mathrm{C}(15)$ & $53.3(9)$ \\
\hline $\mathrm{C}(15)-\mathrm{C}(11)-\mathrm{C}(22)-\mathrm{C}(32)$ & $1.0(10)$ \\
\hline $\mathrm{C}(28)-\mathrm{C}(13)-\mathrm{C}(23)-\mathrm{C}(25)$ & $-123.8(7)$ \\
\hline $\mathrm{N}(12)-\mathrm{C}(13)-\mathrm{C}(23)-\mathrm{C}(25)$ & $52.3(8)$ \\
\hline $\mathrm{N}(9)-\mathrm{C}(17)-\mathrm{C}(24)-\mathrm{C}(27)$ & $58.1(8)$ \\
\hline
\end{tabular}

\begin{tabular}{|c|c|}
\hline N(9)-C(17)-C(24)-C(36) & $-123.6(7)$ \\
\hline $\mathrm{C}(20)-\mathrm{N}(7)-\mathrm{C}(25)-\mathrm{C}(23)$ & $179.9(5)$ \\
\hline $\mathrm{Cu}(2)-\mathrm{N}(7)-\mathrm{C}(25)-\mathrm{C}(23)$ & $47.7(7)$ \\
\hline $\mathrm{C}(13)-\mathrm{C}(23)-\mathrm{C}(25)-\mathrm{N}(7)$ & $-73.2(7)$ \\
\hline $\mathrm{Cu}(1)-\mathrm{O}(6)-\mathrm{C}(27)-\mathrm{C}(18)$ & $137.1(5)$ \\
\hline $\mathrm{Cu}(2)-\mathrm{O}(6)-\mathrm{C}(27)-\mathrm{C}(18)$ & $-17.3(9)$ \\
\hline $\mathrm{Cu}(1)-\mathrm{O}(6)-\mathrm{C}(27)-\mathrm{C}(24)$ & $-41.8(8)$ \\
\hline $\mathrm{Cu}(2)-\mathrm{O}(6)-\mathrm{C}(27)-\mathrm{C}(24)$ & $163.8(5)$ \\
\hline $\mathrm{C}(33)-\mathrm{C}(18)-\mathrm{C}(27)-\mathrm{O}(6)$ & $-178.6(6)$ \\
\hline $\mathrm{C}(33)-\mathrm{C}(18)-\mathrm{C}(27)-\mathrm{C}(24)$ & $0.3(10)$ \\
\hline $\mathrm{C}(36)-\mathrm{C}(24)-\mathrm{C}(27)-\mathrm{O}(6)$ & $176.0(6)$ \\
\hline $\mathrm{C}(17)-\mathrm{C}(24)-\mathrm{C}(27)-\mathrm{O}(6)$ & $-5.6(9)$ \\
\hline C(36)-C(24)-C(27)-C(18) & $-3.0(9)$ \\
\hline $\mathrm{C}(17)-\mathrm{C}(24)-\mathrm{C}(27)-\mathrm{C}(18)$ & $175.4(6)$ \\
\hline $\mathrm{C}(16)-\mathrm{N}(8)-\mathrm{C}(28)-\mathrm{C}(13)$ & $0.5(7)$ \\
\hline $\mathrm{N}(12)-\mathrm{C}(13)-\mathrm{C}(28)-\mathrm{N}(8)$ & $-0.6(7)$ \\
\hline $\mathrm{C}(23)-\mathrm{C}(13)-\mathrm{C}(28)-\mathrm{N}(8)$ & $175.9(6)$ \\
\hline $\mathrm{C}(17)-\mathrm{N}(9)-\mathrm{C}(29)-\mathrm{C}(26)$ & $175.3(6)$ \\
\hline $\mathrm{Cu}(1)-\mathrm{N}(9)-\mathrm{C}(29)-\mathrm{C}(26)$ & $41.3(7)$ \\
\hline $\mathrm{C}(30)-\mathrm{C}(26)-\mathrm{C}(29)-\mathrm{N}(9)$ & $-72.5(7)$ \\
\hline $\mathrm{C}(19)-\mathrm{N}(10)-\mathrm{C}(30)-\mathrm{C}(31)$ & $-0.1(7)$ \\
\hline $\mathrm{Cu}(1)-\mathrm{N}(10)-\mathrm{C}(30)-\mathrm{C}(31)$ & $167.3(4)$ \\
\hline $\mathrm{C}(19)-\mathrm{N}(10)-\mathrm{C}(30)-\mathrm{C}(26)$ & $-177.0(6)$ \\
\hline $\mathrm{Cu}(1)-\mathrm{N}(10)-\mathrm{C}(30)-\mathrm{C}(26)$ & $-9.6(8)$ \\
\hline $\mathrm{C}(29)-\mathrm{C}(26)-\mathrm{C}(30)-\mathrm{C}(31)$ & $-119.2(8)$ \\
\hline $\mathrm{C}(29)-\mathrm{C}(26)-\mathrm{C}(30)-\mathrm{N}(10)$ & $56.8(8)$ \\
\hline $\mathrm{N}(10)-\mathrm{C}(30)-\mathrm{C}(31)-\mathrm{N}(14)$ & $0.0(7)$ \\
\hline $\mathrm{C}(26)-\mathrm{C}(30)-\mathrm{C}(31)-\mathrm{N}(14)$ & $176.4(7)$ \\
\hline $\mathrm{C}(19)-\mathrm{N}(14)-\mathrm{C}(31)-\mathrm{C}(30)$ & $0.0(7)$ \\
\hline $\mathrm{C}(11)-\mathrm{C}(22)-\mathrm{C}(32)-\mathrm{C}(34)$ & $-2.1(10)$ \\
\hline $\mathrm{C}(27)-\mathrm{C}(18)-\mathrm{C}(33)-\mathrm{C}(35)$ & $2.2(11)$ \\
\hline $\mathrm{C}(22)-\mathrm{C}(32)-\mathrm{C}(34)-\mathrm{C}(21)$ & $0.1(10)$ \\
\hline C(15)-C(21)-C(34)-C(32) & $3.0(10)$ \\
\hline $\mathrm{C}(20)-\mathrm{C}(21)-\mathrm{C}(34)-\mathrm{C}(32)$ & $-172.8(6)$ \\
\hline $\mathrm{C}(18)-\mathrm{C}(33)-\mathrm{C}(35)-\mathrm{C}(36)$ & $-2.0(11)$ \\
\hline$C(33)-C(35)-C(36)-C(24)$ & $-0.7(12)$ \\
\hline $\mathrm{C}(27)-\mathrm{C}(24)-\mathrm{C}(36)-\mathrm{C}(35)$ & $3.2(10)$ \\
\hline $\mathrm{C}(17)-\mathrm{C}(24)-\mathrm{C}(36)-\mathrm{C}(35)$ & $-175.2(7)$ \\
\hline
\end{tabular}


Table S3. Hydrogen bond distances and angles for complex $1\left(\AA\right.$ and $\left.{ }^{\circ}\right)$

\begin{tabular}{lcccc}
\hline $\mathrm{D}-\mathrm{H} \cdots \mathrm{A}$ & $\mathrm{d}(\mathrm{D}-\mathrm{H})$ & $\mathrm{d}(\mathrm{H} \cdots \mathrm{A})$ & $\mathrm{d}(\mathrm{D} \cdots \mathrm{A})$ & $<(\mathrm{DHA})$ \\
\hline $\mathrm{N}(8)-\mathrm{H}(8) \cdots \mathrm{Cl}(3) \# 1$ & 0.86 & 2.29 & $3.149(5)$ & 173.9 \\
$\mathrm{~N}(14)-\mathrm{H}(14) \cdots \mathrm{Cl}(4) \# 2$ & 0.86 & 2.24 & $3.089(6)$ & 172.2 \\
\hline
\end{tabular}

Symmetry transformations used to generate equivalent atoms: \#1 : $\mathrm{x}-1 / 2, \mathrm{y}+1 / 2, \mathrm{z} ; \# 2: \mathrm{x}-1 / 2,-\mathrm{y}+3 / 2, \mathrm{z}-1 / 2$.
Table S4. Experimental (X-ray diffraction data for $\mathrm{HL}^{23}$ ) and calculated (DFT) main bond distances $(\AA)$ and angles $\left(^{\circ}\right)$ for HL1 and HL2

\begin{tabular}{lcccc}
\hline HL1 & Exp. & Calc. & HL2 & Calc. \\
\hline $\mathrm{N}(8)-\mathrm{C}(9)$ & $1.70(3)$ & 1.465 & $\mathrm{~N}(8)-\mathrm{C}(9)$ & 1.462 \\
$\mathrm{~N}(8)-\mathrm{C}(7)$ & $1.476(3)$ & 1.468 & $\mathrm{~N}(8)-\mathrm{C}(7)$ & 1.458 \\
$\mathrm{~N}(14)-\mathrm{C}(13)$ & $1.331(3)$ & 1.365 & $\mathrm{C}(14)-\mathrm{C}(13)$ & 1.396 \\
$\mathrm{~N}(14)-\mathrm{C}(15)$ & $1.359(3)$ & 1.382 & $\mathrm{C}(14)-\mathrm{C}(15)$ & 1.395 \\
$\mathrm{~N}(12)-\mathrm{C}(11)$ & $1.363(3)$ & 1.385 & $\mathrm{~N}(12)-\mathrm{C}(11)$ & 1.344 \\
$\mathrm{~N}(12)-\mathrm{C}(13)$ & $1.326(3)$ & 1.315 & $\mathrm{~N}(12)-\mathrm{C}(13)$ & 1.338 \\
$\mathrm{C}(9)-\mathrm{N}(8)-\mathrm{C}(7)$ & $113.34(19)$ & 114.55 & $\mathrm{C}(9)-\mathrm{N}(8)-\mathrm{C}(7)$ & 115.53 \\
$\mathrm{C}(13)-\mathrm{N}(14)-\mathrm{C}(15)$ & $107.31(18)$ & 107.21 & $\mathrm{C}(13)-\mathrm{C}(14)-\mathrm{C}(15)$ & 117.95 \\
$\mathrm{C}(13)-\mathrm{N}(12)-\mathrm{C}(11)$ & $105.61(19)$ & 105.72 & $\mathrm{C}(13)-\mathrm{N}(12)-\mathrm{C}(11)$ & 118.09 \\
\hline
\end{tabular}

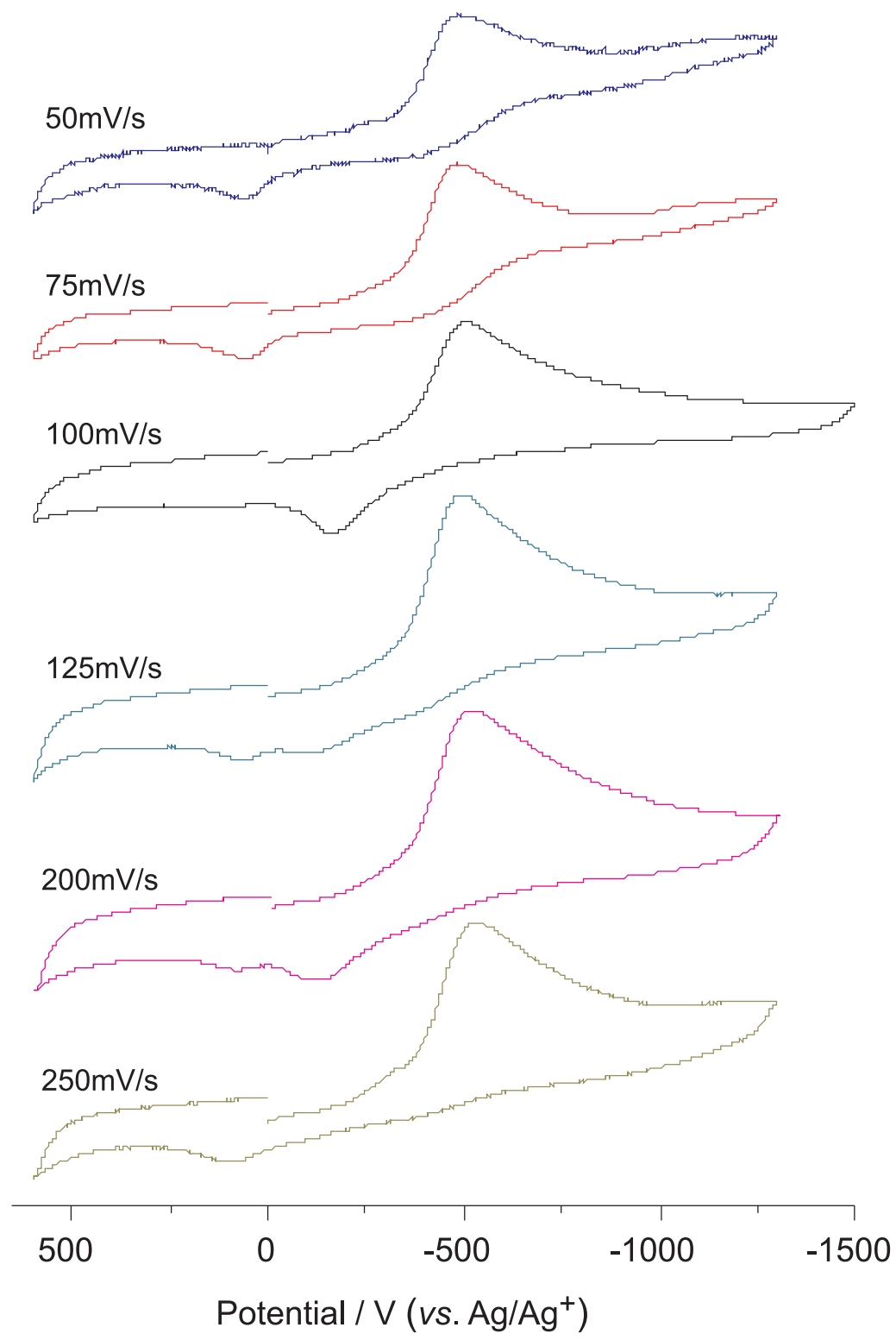

Figure S1. Cyclic voltammograms registered for complex $\mathbf{1}$ in methanol at different scan rates. 


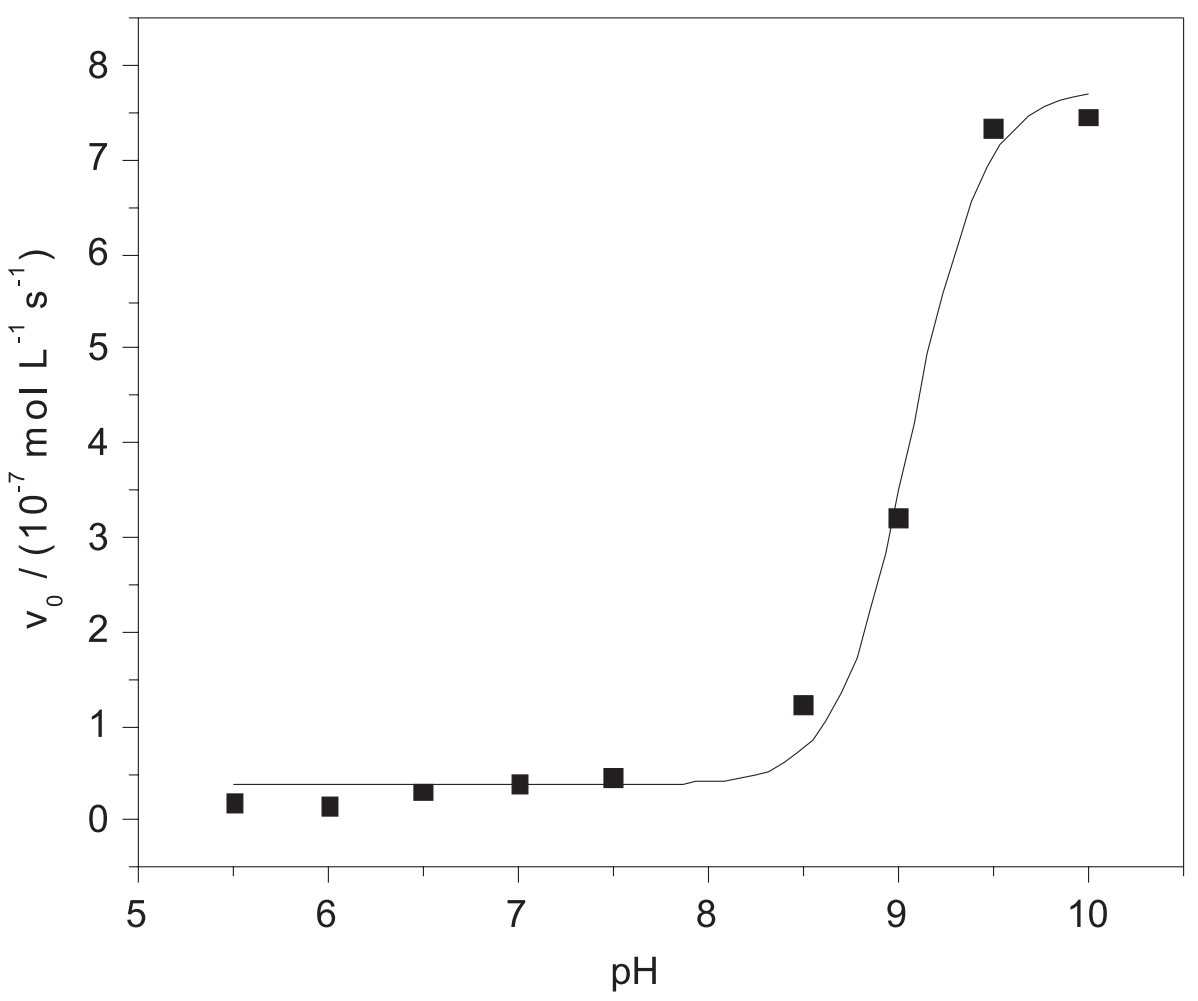

Figure S2. $\mathrm{pH}$ dependence for the oxidation of 3,5-dtbc catalyzed by complex 2, in methanol/water $(30: 1 \mathrm{v} / \mathrm{v})$ solution. Experimental conditions: $[\mathbf{2}]_{\text {final }}=$ $2.4 \times 10^{-5} \mathrm{~mol} \mathrm{~L}^{-1} ;[3,5-\mathrm{dtbc}]_{\text {final }}=5 \times 10^{-3} \mathrm{~mol} \mathrm{~L}^{-1} ;[\text { buffer }]_{\text {final }}=3 \times 10^{-3} \mathrm{~mol} \mathrm{~L}^{-1} ; 25^{\circ} \mathrm{C}$.

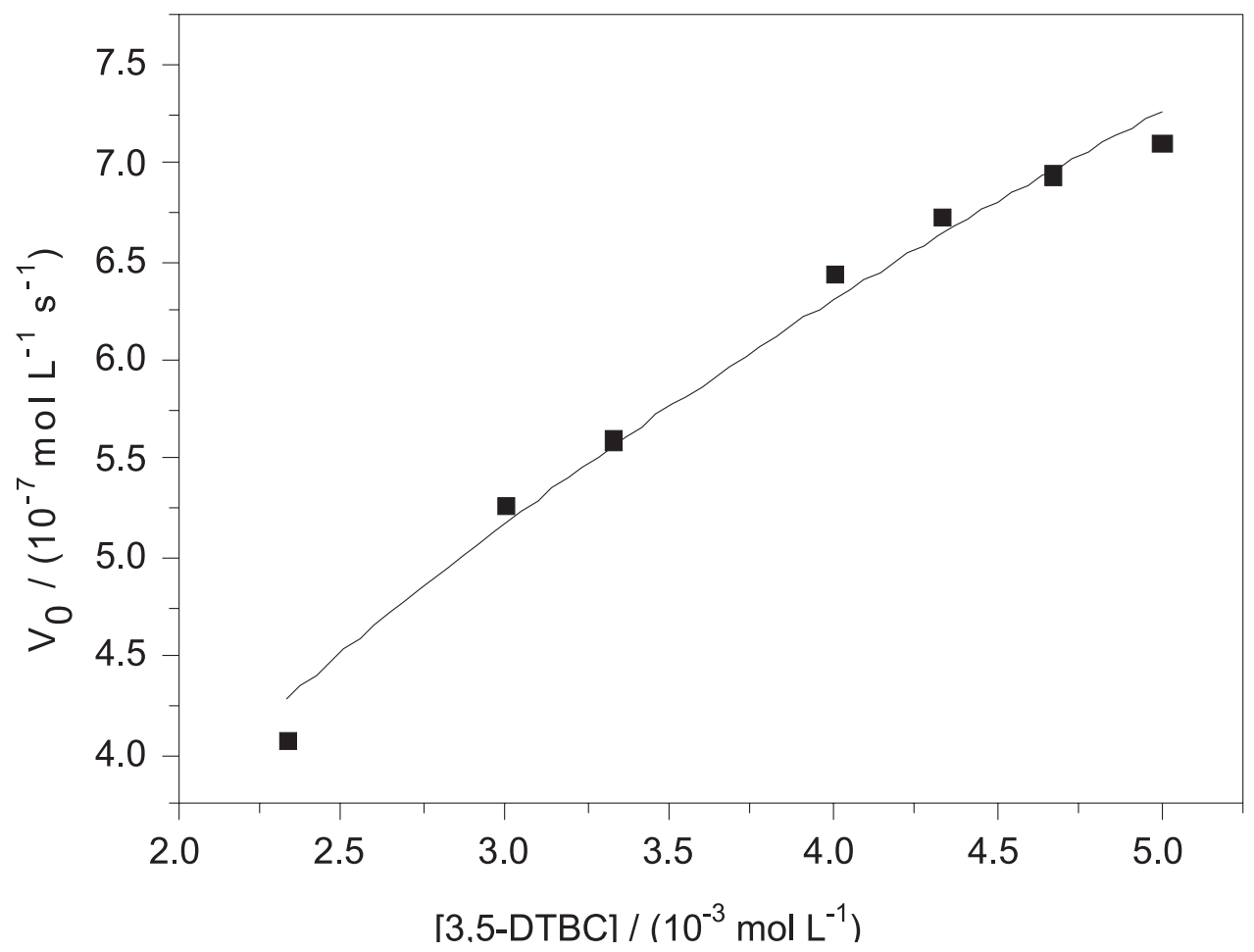

Figure S3. Dependence of the reaction rates on the 3,5-dtbc concentration for the oxidation reaction catalyzed by complex 2 , in methanol/water (30:1 v/v) solution. Experimental conditions: $[2]_{\text {final }}=2.4 \times 10^{-5} \mathrm{~mol} \mathrm{~L}^{-1} ;[3,5-\mathrm{dtbc}]_{\text {final }}=2.33-5.0 \times 10^{-3} \mathrm{~mol} \mathrm{~L}^{-1} ;[\text { buffer }]_{\text {final }}=3 \times 10^{-3} \mathrm{~mol} \mathrm{~L}^{-1} ; \mathrm{pH} 9(\mathrm{CHES} \mathrm{buffer}) ; 25^{\circ} \mathrm{C}$. 